\title{
KISÄLLIEN LAULUT - AGITAATIOTA JA VIIHDETTÄ
}

Lainasävelmätekniikka • mölyköörit • Dallapé $・$ sinipuserot $・$ wandervögel $・$ sjungande gesäller - verivatilaulut - agitaattorit ja tyylin uudistajat - kipparikvartettityyli • funktionaalinen estetiikka $\bullet$ kurinalaisuuden idea $\bullet$ keskusjohtoisuus $•$ järjestömusiikki

Tämä kirjoitus käsittelee Suomen työläisnuorisoliikkeen kisälliryhmien historiaa ja heidän lauluperinteensä ominaispiirteitä. Kisällilaulu on jo historiaa. Sen synty ajoittui 1920 -luvulle ja huippukausi toisen maailmansodan jälkeiselle vuosikymmenelle. Kyseinen musiikki säilyi työväen järjestönuorten musiikkiharrastuksen osana aina 1960-luvun puoliväliin asti.

Otsikon käsitteet agitaatio ja viihde kuvaavat hyvin kisälliperinteen rajoja. Kisälliryhmien ohjelmisto ulottui hyvinkin agressiivisistä poliittisista lauluista harmittomaan kuplettiviihteeseen. Väliin mahtui kevyempää poliittista satiiria, moralistisia valistuslauluja, aatteellisia marsseja sekä tavallisia kansanlauluja.

Kisällien propagandistiset ja viihteelliset laulut olivat lähes 40 vuoden ajan keskeinen osa järjestäytyneen työläisnuorison ohjelmatoimintaa. Kisälliharrastus kuului järjestöjen nuorisokasvatukseen ainakin kahdessa mielessä: Se oli ensinnäkin tärkeä poliittisen kasvatuksen väline, sillä nuorisojohtajat pitivät sen propaganda-arvoa erityisen korkeana. Kisällitoimintaan osallistuvat nuoret olivat yleensä hyvin perillä poliittisista ja ideologisista kysymyksistä. Tässä mielessä kisällilaulun historia on erottamaton osa työläisnuorisoliikkeen poliittista historiaa. Monet kisälliperin- 
teen piirteet voidaan käsittää ainoastaan järjestötoiminnan kehityksen valossa.

Mutta toisaalta kisälliharrastus leikkasi yhteen työläisnuorison musiikkikasvatuksen kanssa. Taidekasvatuksen kannalta kisällilaulu oli tosin varsin epäkiitollinen alue. Kisällien musiikki oli 'epätaiteellista', selvässä ristiriidassa virallisen musiikkikasvatuksen arvomaailman kanssa. Monet työväen sivistysjohtajat eivät pitäneet sitä musiikkina lainkaan. Silti - ja ehkäpä juuri siitä syystä - myös kisällilaulun historiassa heijastuvat ne murrokset ja vastakohdat, jotka syntyivät, kun musiikillinen kansanvalistus kohtasi rahvaan musiikkimaailman.

Kisällien laulut kuuluvat jo menneisyyteen. Se näkyy tavallaan myös tämän työn sisällössä. Olen jäänyt tietyissä kohdin väkisinkin tutkimuskohteeni ulkopuolelle. Lähes kaikki tutkimusaineisto on toisen käden lähteitä, kuten järjestölehtien kirjoituksia ja muistitietoa. Ainoa merkittävä primaariaineisto koostuu lauluteksteistä. Mutta niidenkin käyttöä rajoittaa kontekstitietojen puutteellisuus - teksteistä ei kovinkaan usein ilmene niiden tekijää tai tekoaikaa, monesti ei tiedetä edes sävelmää, jolla teksti on laulettu. Autenttisia äänitteitä ja filmejä kisällien esityksistä on äärimmäisen vähän. Siten esimerkiksi esitystyyliä koskeva analyysi jää väkisinkin spekulatiiviseksi. Sen uhallakin pyrin vastaamaan myös kysymyksiin: millaista kisällilaulu oli, miten kisällit sitä lauloivat, miten he liikkuivat laulaessaan ja miten perinne muuttui vuosikymmenten saatossa?

\section{Työväenliike ja kulttuurilainat}

Voidaan perustellusti väittää, että kisällilaulu oli Suomen työväenliikkeen omintakeisinta musiikkia. Se oli tämän osakulttuurin omaa musiikkia. Se ei levinnyt liikkeen ulkopuolelle, ja järjestöjen ulkopuoliset ihmiset eivät tienneet siitä juuri mitään. Mutta 'oma musiikki' on tässä yhteydessä varsin suhteellinen käsite. Itse asiassa kisällilaulu oli lähes täydellistä kulttuurilainaa. Yhtäältä se käytti hyväkseen oman aikansa populaarimusiikkia, kuten kuplettilaulua ja iskelmiä sekä myös näitä vanhempia kansanlauluja. Näistä aineksista kehittyi suomalaisen kisällilaulun muoto: sävelmistö, säestyssoittimet ja sanoitustekniikka. Myös monet esitystyylin aspektit, kuten laulutapa, säestystapa sekä liikunnalliset ja miimiset piirteet polveutuivat suomalaisesta kansanperinteestä ja varhaisista viihteen muodoista. Toisaalta kisällien laulut olivat osa yleiseurooppalaista agitaatioperinnettä, joka syntyi ja kulkeutui maasta toiseen 1920-luvun kuluessa. Laulujen sisältö ja tarkoitus, lauluryhmien organisaatio ja jopa kisällilaulu-nimi- 
tyskin perustuivat ulkomaisiin esikuviin.

Jotta kisällilaulun lainapiirteet ymmärtäisi oikeassa valossa, on syytä palauttaa mieleen koko työväenkulttuurin yleinen olemus. Jos hieman kärjistää, voi sanoa, että Suomen työväenliikkeen taideharrastus perustui suurimmalta osaltaan porvarillisen taide-elämän muotojen ja tyylien lainailuun. Erityisen selvästi tämä koski työväen kuorolaulua, torvisoittoa ja teatteria; ne eivät usein edes sisältönsä puolesta poikenneet porvarillisesta yleiskulttuurista. Myös vanhemman työväenmusiikin aatteellisin osa, joukkolaulu perustui pääosin lainasävelmille. Työläisrunoilijat kirjoittivat tuttuihin marsseihin ja makuntalauluihin vain uudet proletaarihenkiset sanat, ja uusi laulurepertuaari oli valmis. Myös laulurunouden muoto oli ulkoista lainaa - työläisrunoilijat pitäytyivät varsin pitkälle vanhakantaisissa muotoratkaisuissa ja kirjoittivat laulutekstinsä vuosisadan vaihteen korkealentoiseen ylätyyliin. Riimittelytekniikan kömpelyys tosin saattoi tuoda lauluihin omintakeista 'prolesävyä'. (Vrt. Palmgren 1965, 218).

Jo aivan vuosisadan alussa, 1910-luvulla työväenliikkeen lauluntekijät huomasivat, että yleiskulttuurista voitiin lainata esitystyylejä erityisen vastakohtatekniikan avulla. Vastakohtiin perustuva parodiointi synnytti omalaatuisen laulun lajin, mölyköörit. Ne olivat sekakuoroja, jotka esittivät ilman säestystä satiirisia lauluja. Laulujen iva kohdistui mm. pappeja ja valkokaartia vastaan.

Vastakohtaperiaate näkyi mölyköörien laulussa pääasiassa kahdella tavalla. Ryhmien esitystyyli oli ensinnäkin taiteellisen kuorolaulun täydellinen vastakohta. Nimensä mukaisesti mölyköörit lähinnä huusivat ja mellastivat esiintyessään. Huumoria korostettiin myös sirkusmaisilla esiintymisasuilla; köörin johtaja johti möykettä esimerkiksi soppakauhalla tai saunavastalla. Lisäksi mölyköörit saattoivat lainata sävelmänsä siten, että ne muodostivat täydellisen vastakohdan tekstin sanoman kanssa. Niinpä köörit veisasivat uskonnonvastaisia lauluja virren sävelellä. Veisuuseen liittyi usein pilasaarna, joka tietenkin korosti esityksen ironisuutta. (Saunio \& al. 1978, 23-25; TMI:n mölyköörikokoelma).

\section{Kisällien sävelmät - sotilasmarsseista rock'n'rolliin}

Työväentaide oli tottunut lainailemaan ideoita ja tyylejä yleiskulttuurista. Tuntuu siten täysin luonnolliselta, että 1920-luvun työläisnuorten lauluryhmät hakivat esikuvansa jo olemassaolevista musiikkiperinteistä. Alusta lähtien lauluntekijät näyttävät tajunneen, että hyvässä kappaleessa tuli olla kaikille tuttu, kansanomainen sävelmä. Niinpä erilaiset kansanlaulut ja 
kansanlaulun tapaiset koululaulut olivat hyvin suosittuja lainasävelmiä koko kisällilaulukauden ajan. Sellaiset sävelmät kuten Isontalon Antti, Honkain keskellä, Kukkuva kello, Hepokatti ja Tammerkosken sillalla löysivät tiensä lukemattomiin kisälliteksteihin vuosien saatossa. 1

Vuosisadan vaihteen joukkolaulujen tekotapa oli myös kisällien tiedossa. Myös kisällilaulujen tekijät sepittivät runojaan sotilasmarssien ja kansallisten laulujen sävelmiin. Tämä oli tyypillistä erityisesti vanhemmalle kisällilaululle. Esimerkiksi Sos.dem. Työläisnuorisoliitto julkaisi 1930-luvulla laulumonisteita, joista lähes jokainen sisältää propagandalauluja isänmaallisten marssien ja laulujen sävelmiin. Näissä kappaleissa kisällilaulun parodiavaikutus saavutti usein huippunsa. Kun lauluntekijät lainasivat sävelmiä, he valitsivat ne usein noudattamalla samaa vastakohtaperiaatetta, jota jo mölyköörit olivat suosineet: porvarilliseen aatemaailmaan kytkeytyneitä sävelmiä laulettiin nyt sanoilla, jotka pyrkivät arvostelemaan ja vastustamaan tuota aatetta.

Näiden laulujen tekstit suuntautuivat usein valkoista Suomea, oikeistoradikalismia tai sotaa vastaan, ja ne saivat kehyksekseen mm. Jääkärimarssin, Porilaisten marssin, Sotilaspojan, Oolanninsodan, 30-vuotisen sodan marssin, Hämäläisten laulun tai Sillanpään marssilaulun sävelmän.2 Hyvä esimerkki tästä laulutyypistä on $\mathrm{H}$. Käpälämäen (Vihtori Huhdan) 'Nykyisyyden hymni' vuodelta 1931. Laulu esitettiin Karjalan ratsujääkärien marssin sävelellä. Siinä Suomen Valkoisen armeijan marssi muodostaa tehokkaan kontrastin tekstille, joka suomii Lapuan liikettä ja sitä tukevia oikeistovoimia sekä ylistää sosialidemokratiaa.

NYKYISYYDEN HYMNI

Sanat: H. Käpälämäki

Sävel: "Kaunis Karjala"

Koko Suomenmaa

täynn' on hulinaa

Pohjanmaalta alkaen se Karjalaankin saa

Häme, Savo, Turunpuoli,

kaikkialla sama huoli

kaulahamme sidotahan silmukkaa.

Yksimielisinä rynnätkää

tunnuslause meillä ompi tää

So sialide mokraat ti

siinä on aina oiva määränpää! 
Kaikkein kauhistus,

ompi kokoomus,

bobrikoffilaiseks' jota kansa nimittää.

Kerran huusit auttajalles:

Döitslanti, oi yber alles;

Saksmannille myyty oisi Suomi tää.

Yksimielisinä rynnätkää jne.

Nousi Lapua,

huusi apua

kommunismin alta isänmaata auttamaan,

autot kulki pitkin öitä,

tehtiin hulikaanitöitä

auttamiseks' muka polon isänmaan.

Yksimielisinä rynnätkää jne.

(STN:n kisällilauluja 2, n. 1931)

Kisällilaulujen kolmas suuri lainasävelmävarasto oli kuplettiperinne. Kuplettilaulu oli saavuttanut suuren suosion työväestön jo ennen 1920-lukua. Esimerkiksi Suomen Työväen Musiikkiliiton ensimmäisillä laulujuhlilla vuonna 1921 kupletisti Tatu Pekkarisen viisutilaisuus oli juhlien ainoa kassamenestys. Varsinaiset konsertit, joissa kuultiin mm. kuorolaulua ja torvisoittoa, kärsivät kaikki yleisönpuutteesta. (Huhta 1938, 6).

Vaikka kupletti sai 1930-luvulle tultaessa väistyä uuden kansallisen iskelmämusiikin tieltä, se säilytti asemansa kisällilaulajien keskuudessa. Erityisesti J. Alfred Tannerin kupletit olivat suosittuja lainasävelmiä aina 1950-luvulle saakka; kisälli- ja kisällitärryhmät esittivät niitä myös alkuperäisessä asussaan varsin yleisesti. Kuplettilaulu oli myös ilmeisen tärkeänä esikuvana kisällien esitystyylille. Mm. ryhmien käyttämät liikkeet ja eleet olivat suoraa sukua kuplettilaulajien esitysmaneereille.

Uusi tanssimusiikki, 'jazz' alkoi 1920-luvulla saada jalansijaa suomalaisten musiikkimaailmassa. Myös työväen nuorisoliikkeessä syntyi musiikkiryhmiä, jotka lauloivat ja soittivat - etupäässä haitarilla, mandoliinilla ja banjolla - tätä uutta suosiomusiikkia. Todellisuudessa tämä 'jazz' oli perin kaukana varsinaisesta jazzista; se koostui etupäässä jenkoista, polkista, valsseista, nopeista fokstroteista ja muista schlagersävelmistä. (Vrt. Jalkanen 1975, 141-162).

Tunnetuin esimerkki työläisnuorten 'jazz'-ryhmästä oli helsinkiläinen Rajamäen Pojat. Ryhmä perustettiin aivan 1920-luvun alussa; sen ensim- 
mäinen julkinen esiintyminen oli muistitiedon mukaan vuonna $1923 .{ }^{3} \mathrm{Ra}-$ jamäen Pojat oli tavallaan yhdistävä lenkki vanhemman mölyköörilaulun ja kisälliperinteen välillä. Oireellisesti ryhmää kutsuttiin myös nimellä 'Rajamäen kööri'. 4 Lisäksi sen keskeisinä ohjelmanumeroina näyttävät olleen ns. puurovirret ja muut kronikat, jotka kertoivat Sörnäisten nuoriso-osaston toiminnasta ja kustakin osastolaisesta erikseen. Myös mölyköörit olivat esittäneet samanlaisia lauluja. (Saunio \& al. mt., 25; Mölyköörikokoelma, TMI).

Mutta toisaalta Rajamäen Pojat erosi jo selvästi mölykööriperinteestä: ryhmään kuului pelkästään poikia, ja he säestivät lauluaan haitarilla ja banjolla. Ilmeisesti uusi tanssimusiikki vaikutti Rajamäen Poikien esitystyyliin enemmän kuin kuorolaulu - toisaalta kyllä tiedetään, että ryhmän jäsenet osallistui aktiivisesti nuoriso-osastonsa kuoron, Laulu-Veikkojen toimintaan. 5

Innostus 'jazziin' oli rajamäkeläisten keskuudessa niin suuri, että ryhmän ydinjoukko perusti vuonna 1925 erillisen tanssiorkesterin. Sen nimeksi tuli Dallapé. Dallapéstä kehittyi 1930-luvulle tultaessa Suomen tunnetuin ja suosituin tanssiorkesteri, kymmenien muiden yhtyeiden tyylillinen esikuva. Näin työläisnuorten poliittinen laulu liittyi saumattomasti Suomen kansallisen populaarimusiikin kehitykseen. (Jalkanen mt., 142-150; Saunio \& al. mt., 27-28).

Dallapén perustaminen ei suinkaan lopettanut Rajamäen Poikien toimintaa. Itse asiassa juuri vuoden 1925 jälkeiseltä ajalta on säilynyt lauluvihko, jonka perusteella saa hyvän käsityksen ryhmän ohjelmistosta. Mm. monet kommunistisen nuorisoliikkeen johtohenkilöt - Ludvig Kosonen, Gunnar Laine ja Armas Äikiä - kirjoittivat tuolloin pojille monenlaisia laulutekstejä; mukana oli myös varsin kiivaita poliittisia ivalauluja. 6 Täydellä syyllä Rajamäen Poikia voi pitää Suomen ensimmäisenä agitaatiolaulun kokoonpanona. Se oli kisälliperinteen pioneeri.

Rajamäen Poikien kiinteä suhde uuteen tanssimusiikkiin näkyi myös siinä, että he käyttivät useissa lauluissaan ajan suosituimpia tanssisävelmiä. Mm. fokstrotit Honolulu, Marokko ja Puuseppä ovat lainasävelminä ryhmän lauluvihkossa. Sama käytäntö jatkui muiden propagandistiryhmien lauluissa 1920-luvun lopulla, ja seuraavalla vuosikymmenellä myös Sos.dem. Työläisnuorisoliiton kisällit suosivat viisuissaan uusia tanssisävelmiä. Päivän iskelmät valtasivat yhä enemmän alaa sodanjälkeisessä kisällilaulussa, ja 1950-luvulla oltiin jo tilanteessa, että enemmistö ryhmien käyttämistä lainasävelmistä oli suomalaista levytettyä tanssimusiikkia tai käännösiskelmiä. Erityisen suosittuja olivat jenkat ja valssit, mutta lauluntekijät lainailivat lähes kaikentyyppisiä tanssikappaleita - fokstrotteja, tangoja, latinalaisrytmejä, jopa rockiakin. 
Kisällilaulu oli tyyliltään varsin kansallista; se pohjautui ja tukeutui kehityksessään Suomen kansankulttuurin musiikillisiin aineksiin. Lisäksi työväenliike tunsi poliittisen pilkkalaulun idean jo ennen kisällilaulun aikaa mölyköörien muodossa.

Mutta kisällilaulu ei silti ollut pelkästään suomalaisen kansankulttuurin tuote. Monet sen piirteistä, jopa nimeä myöten, tulivat työväenliikkeeseen ulkomaisia järjestökanavia pitkin. Jo ennen kisälliperinteen muotoutụmista työläisnuorisoliike oli jakautunut kahteen osaan, kommunistiseen ja reformistiseen suuntaan. Järjestöjako oli sattunut vuonna 1921 ja se vastasi Suomen työväenliikkeen yleistä kehitystä (Esim. Parkkari 1970, 99-122). Meidän on syytä tarkastella kisällilaulun ulkomaisia vaikutteita kummankin suunnan osalta erikseen.

\section{Sinipuserot ja propagandistit}

Kommunistikisällien esikuvana on pidettävä sinipuseroliikettä, joka syntyi Venäjällä vallankumouksen jälkeisinä vuosina. Ensimmäinen ryhmä perustettiin vuonna 1923 Moskovassa. Sinipuserotoiminta kasvoi vuosikymmenen puolen välin jälkeen todelliseksi massaliikkeeksi: Neuvostoliitossa oli parhaimpana aikana noin 10000 ryhmää, joista pari sataa toimi ammattimaisina. Sinipuseroiden näytökset koostuivat teatteriesityksistä, esitelmistä, sketseistä, joukkolausunnasta, soittoesityksistä ja lauluista; toiminnan päämääränä oli ennen muuta poliittinen valistus ja propagandanteko. (Bramsjö \& al. 1978, 10-14).

Lokakuussa 1927 ensimmäinen neuvostoliittolainen sinipuseroryhmä teki ulkomaankiertueen. Se esiintyi 25:ssä Saksan kaupungissa ja teollisuuskeskuksessa noin 150000 kuulijalle. Ryhmä saavutti suuren menestyksen, ja varsin pian saksalaiset nuorkommunistit alkoivat perustaa vastaavanlaisia Agitprop-ryhmiä keskuuteensa. (Ensimmäinen saksalainen ryhmä oli aloittanut toimintansa jo saman vuoden keväällä.) Saksassa tällaiselle harrastukselle oli vankka perusta, sillä aivan 1920-luvun alusta lähtien maahan oli kasvanut laaja työläisteatteriliike. Nämä teatterit olivat tunnettuja iskevistä revyynäytöksistään, joissa musiikilla oli tärkeä osuus. (Bramsjö \& al. mt., 14-15; Hoffmann \& al. 1972, 209-211, 240-248).

Neuvostoliittolaisten sinipuseroiden kiertue herätti melkoista huomiota koko eurooppalaisessa kommunistisessa liikkeessä. Vuodesta 1928 lähtien vastaavia agitaatioryhmiä syntyi varsin moneen maahan. Sinipuserotoimintaa oli mm. Tsekkoslovakiassa, Tanskassa, Ruotsissa, Englannissa ja 
Yhdysvalloissa. (Bramsjö \& al. mt., 14).

Neuvostoliittolaisten agitaatioryhmien toiminta sai Suomessa vastakaikua jo ennen sinipuseroiden Euroopan läpimurtoa. Suomalaisilla kommunistinuorilla oli 1920-luvulla hyvin kiinteät suhteet itärajan taakse maanalaisen SKP:n johto oli Moskovassa ja puolue toimi sieltä käsin. Myös tiedot uuden sosialistisen yhteiskunnan kulttuurielämästä kulkeutuivat tänne nopeasti. Niinpä Rajamäen Pojillakin oli suoria yhteyksiä Neuvosto-Venäjälle jo ennen vuosikymmenen puoliväliä - ryhmä teki Venäjänkiertueenkin, ilmeisesti vuonna 1924. Pojat ottivat ohjelmistoonsa mm. Leningradin punaupseerikoulun lauluja; on myös hyvin mahdollista, että ryhmä alkoi pitää yhtenäisiä esiintymisasuja - ruskeita liittopuseroita Neuvostoliitosta saadun esikuvan innoittamana. Sinipuseroryhmät kantoivat nimensä mukaisesti sinisiä esiintymisasuja. (Saunio \& al. mt., 27, 31).

Vuodesta 1925 lähtien helsinkiläisillä työläisnuorilla oli jo toinenkin ohjelmaryhmä, jonka nimi oli Pasilan Laulu-Jussit. Sen lauluvihko osoittaa, että ryhmä seurasi tyylillisesti Rajamäen Poikien jälkiä: Laulu-Jussien kuplettimaiset viisut sisältivät kirkon, salaisen poliisin ja sodanvastaista propagandaa; ne käsittelivät myös vähemmän poliittisia, mutta ajankohtaisia aiheita kuten radiotoimintaa ja muotihullutuksia.7

Kuitenkin vasta kesällä 1927 kommunistinuorten propagandistitoiminta alkoi laajentua ympäri maata. Sörnäisten nuoriso-osastoon syntyi uusi lauluryhmä Meijän Pojat. Samalla vanhempi Rajamäen ryhmä loittoni kommunistisesta agitaatiosta - heidän laulujensa sanoittajaksi nousi nyt pakinoitsija Ahti H. Einola (Gabriel Tossu), joka sittemmin 1930-luvulla oli keskeisimpiä sosialidemokraattisten kisällilaulujen sepittäjiä.8

Kommunistinuorten runontekijät alkoivat nyt sommitella agitaatiokappaleita Meijän Pojille. Heistä tuli esikuva monille muille ohjelmaryhmille, joita kesästä 1927 alkaen perustettiin ympäri Suomea.

Vuosikymmenen lopulla propagandistitoiminta sai erityisen suuren merkityksen vasemmistolaisten työläisnuorten keskuudessa. Kommunistinen nuorisoliike ei voinut enää toimia normaalin järjestösysteemin avulla, sillä kaikki sitä lähellä olevat järjestöt oli julistettu laittomiksi ja lakkautettu oikeuden päätöksillä. Propagandistien toiminta oli nyt lähes ainoa keino politiikan tekoon; niinpä ohjelmaryhmiä syntyi syksystä 1927 lähtien kymmenittäin. Esimerkiksi kesällä 1928 Lahden opintopäiville osallistui 78 propagandistiryhmää - suurin osa niistä oli lauluryhmiä, mutta joukkoon kuului myös poikkitaiteellisia sinipuseroryhmiä ja lausuntakuoroja. Seuraavana vuonna kommunisteja lähellä olevat ohjelmaryhmät järjestäytyivät erityisten propagandakeskusten ympärille. Keskusten tehtävä oli välittää ohjelmistoa ja harjoittaa ohjaustoimintaa. Suurin niistä oli pääkaupungin Helsprokeskus, joka koordinoi koko maan toimintaa. 
Syksyllä 1929 liike oli laajimmillaan. Maanalaisen Suomen Kommunistisen Nuorisoliiton laatiman tilaston mukaan propagandistiryhmiä oli tuolloin yhteensä 252 ; niistä lauluryhmiä 120 , sinipuseroita 30 , joukkolausuntaporukoita 40 ja "sekaryhmiä" 70. (Parkkari mt., 183).

Propagandistiryhmien organisaatio oli varsin selvä kopio Neuvostoliiton sinipuseroliikkeestä, joka sekin oli jakautunut ympäri neuvostovaltiota paikallisiin ohjelmakeskuksiin (Bramsjö \& al. mt., 12). Sen sijaan yllä olevasta tilastosta voi huomata, ettei varsinainen sinipuserotoiminta levinnyt sellaisenaan kovin laajalle Suomessa. Se jäi lisäksi kovin lyhytikäiseksi: vuoden 1930 jälkeen sinipuseroryhmiä ei Suomessa enää ollut. 9

Mutta yksi osa sinipuseroperinteestä välittyi suomalaisten kommunistinuorten agitaatioharrastuksiin ja myöhempään kisällilauluun pysyvästi: ns. elävä sanomalehti - esitykset. Elävä sanomalehti oli sinipuseroiden ohjelmanumero, jossa ryhmä pyrki eri keinoin välittämään päivän sanomalehden koko sisällön yleisölleen. Esitykset koostuivat mm. vuoropuheluista, runoista, puheista ja lauluista, ja ryhmän jäsenet käyttivät apunaan suuria lavasteita, esimerkiksi kookkaita sanomalehden sivuja, joiden keskellä olevasta reiästä pilkisti esittäjän pää - lausumassa tai laulamassa kyseisen sivun sanomaa. 1920-luvun Venäjällä näillä näytöksillä oli jopa käytännön merkitys tiedonvälityksessä, koska lukutaidottomuus oli yleistä monilla alueilla. (Bramsjö \& al. mt., 10).

Elävä sanomalehti -esitykset tulivat Suomessakin tunnetuiksi 1920-luvun lopulla. Näitten esitysten mukana kulkeutui suomalaiseen kisällilauluun periaate, joka leimasi erityisesti kommunistiryhmien toimintaa koko kisällilaulukauden. Sen mukaisesti hyvän kisälliryhmän tuli aina pyrkiä esityksissään ehdottomaan tuoreuteen. Seuraava katkelma on Suomen Demokraattisen Nuorisoliiton Terä-lehdestä vuodelta 1945. Se kuvaa varsin osuvasti ajattelua, joka ohjasi kisällien jatkuvaa pyrkimystä ajankohtaisuuteen:

-- Isku tuntuu kipeämmin ja sen teho on suurempi, jos voimme heti tuoreeltaan puuttua asiaan. - - Arvaattehan, miten yleisöä naurattaisi, jos esimerkiksi voisimme laulaa siitä, miten eilen, tiistaina kunnankirjuri, tunnettu "iikolli" ja taarttumusmies, oli kärähtänyt hamstratessaan viisi kiloa voita ja vielä kunnan varoilla. Se valssin tahti soisi asianomaisen ja muidenkin hänen hengenheimolaisensa korvissa varmaan vuosia. (Anon. 1945a).

Samainen 'Laulava sanomalehti' -artikkeli sisälsi myös ehdottoman vaatimuksen kaikille kisälliryhmille. Sen mukaan "sisällöltään vanhentunut laulu on armotta poistettava ohjelmistosta, vaikkei olisi ainoatakaan esityskelpoista laulua panna tilalle". On mahdotonta jälkikäteen arvioida, 
kuinka uskollisesti yksittäiset ryhmät noudattivat tätä kehoitusta. Joka tapauksessa tiedetään, että nopeimmat ryhmät saattoivat illalla käsitellä lauluissaan samaa asiaa, joka oli ollut aamun lehtien pääuutinen. 10

\section{Wandervögel ja Laulavat kisällit}

Suomen sosialidemokraattisten nuorten kisällilaulu sai esikuvansa suoraan Ruotsista. Joskaan ei voida kokonaan sulkea pois sitä mahdollisuutta, etteikö kommunistinuorten propagandistitoiminta olisi toiminut jonkinlaisena virikkeenä sosialidemokraateille, kun he käynnistivät omaa laulutoimintaansa. 11

Meidän on tässäkin tapauksessa palattava vuoteen 1927 . Tuon vuoden kesällä ruotsalaiset sos.dem. nuoret alkoivat suunnitella uudenlaisten lauluryhmien perustamista. Idea tähän tuli varsin yllättävältä suunnalta, Saksan porvarillisesta nuorisomusiikkiliikkeestä. Saksassa ns. Wandervogel-liike oli jo vuosisadan alussa koonnut nuorisoa kansanlaulun ja romanttisen luontomystiikan pariin. Liikkeen johtomiehillä oli idealistinen käsitys, että heidän piti kasvattaa Saksan nuoriso alkuperäisen, ristiriidattoman yhteisön, Gemeinschaftin jäseniksi. Liikkeen ideologit katsoivat, että aidolla ja turmeltumattomalla kansanlaululla oli tässä kasvatustyössä ratkaiseva rooli. Puhdas kansanlaulu jalostaisi nuorisoa, ja uusi yhteisömuoto pelastaisi Saksan luokkayhteiskunnan ristiriidoista ja rappiosta. Ensimmäisen maailmansodan jälkeisissä sekavissa oloissa nuorisomusiikkiliikkeen ohjelma saavutti huomattavan kannatuksen saksalaisen keskiluokan risnrison parissa - Saksan alennustila ja perinteisten arvosysteemien rikkoutuminen sai juuri tuon yhteiskuntaryhmän hämmennyksen valtaan, ja menneisyyttä ihannoiva nuorisomusiikkiliike tarjosi heille sopivan vastakulttuurin, johon turvautua. Liike vahvistui 1920-luvun alussa ja laajeni ympäri Saksaa. (Kolland 1979, 8-11, 25-32; Hodek 1977, 22-49).

Mutta miten varsin konservatiivinen nuorisomusiikkiliike saattoi vaikuttaa Ruotsin työväenliikkeen musiikkitoimintaan? Stefan Bohman on väitöskirjassaan selvittänyt, kuinka monet Ruotsin sosialidemokraattisista johtajista omaksuivat 1920-lukuun mennessä hyvin kansallisromanttisen ajattelutavan. Tämä näkyi erityisen selvästi heidän kulttuurinäkemyksissään. Heitä viehättivät samat folklorismin ihanteet kuin vuosisadan vaihteen porvaristoakin - paluu raikkaaseen luontoon epäterveellisen kaupunkielämän vastapainona. Nämä ihanteet siirtyivät myös nuorisokasvatukseen, ja esimerkiksi sos.dem. nuorten laulukirjoihin ilmaantui 1920luvulla oma luonto- ja vaelluslaulujen osasto. Samalla vanhemmat työväenlaulut, jotka korostivat luokkaristiriitaa, saivat yhä pienemmän 
osan kirjojen sisällöstä. Ne korvautuivat lauluilla, jotka hyvin yleisellä tasolla viestivät vapauden ja hyvinvoinnin toiveita ja vaatimuksia. (Bohman 1985, 21-29, 34-39, 86-99).

Ruotsin sosialidemokraatit eivät tietenkään omaksuneet Saksan nuorisomusiikkiliikkeen ajatusmaailmaa sellaisenaan. Saksalainen vaikutus näkyi lähinnä nimityksissä ja toimintamalleissa. Osa Saksan musiikkiliikkeestä oli järjestäytynyt erityisiin 'musiikkikiltoihin'. Mahdollisesti tämä viittaus keskiaikaiseen ammattikuntalaitokseen oli virikkeenä sille, että Ruotsin sosialidemokraatit alkoivat kutsua uusia lauluryhmiään laulaviksi kisälleiksi (Sjungande gesäller).(Vrt. Kolland mt., 9).

Ensimmäinen ryhmä muodostettiin syksyllä 1927. Kuten saksalaiset wandervogelit, myös kisällit olivat pukeutuneet vaellusasuihin, pussihousuihin, maihinnousukenkiin ja sarkatakkiin. Kevään 1928 vaalien alla sosialidemokraatit huomasivat, että kisällit kykenivät jakamaan tehokkaasti myös poliittista valistusta - he olivat saavuttaneet suuren suosion yleisön keskuudessa. Nyt kisälliryhmiä perustettiin ympäri Ruotsia. Wandervogelperinne saattoi olla esikuvana myös siihen, että kisällit kiertelivät paikkakunnalta toiselle, nuoriso-osastosta toiseen. He yrittivät esimerkeillään kannustaa nuorison musiikkiharrastusta ja lisätä sen poliittista tietoisuutta. (Bohman mt., 94-95,110-111).

Yksi ruotsalainen ryhmä, kolme poikaa vieraili kesällä 1928 Suomessa, kun Sosialidemokraattinen Työläisnuorisoliitto piti edustajakokoustaan. Sen antaman esimerkin innostamana Helsingin sos.dem. nuoriso-osaston pojat kokosivat viisihenkisen lauluryhmän ja ottivat nimekseen Laulavat kisällit. Toinen ryhmä perustettiin Tapanilaan, jossa jo ennestään toimi Blomqvistin laulava perheyhtye. Siitä kehittyi kisälliryhmä Hyrskynmyrsky. Ruotsalaisen esimerkin mukaisesti ryhmät alkoivat tehdä vierailumatkoja muihin nuoriso-osastoihin. Muutamaa vuotta myöhemmin, 1930luvun alussa sos.dem. nuoret perustivat kisälliryhmiä eri puolilla Suomea. 12

Näin kumpikin suomalaisen työläisnuorisoliikkeen osapuoli oli omaksunut agitoivan lauluperinteen omien ulkomaisten järjestökontaktien johdattamina. 1930-luvun taitteessa kommunistinuorten julkinen toiminta tyrehtyi täysin; myös kaikki propagandistiryhmät joutuivat Lapuan liikkeen varjossa lopettamaan toimintansa. Kommunistinen liike painui nyt kokonaan maan alle, mutta alkoi vuosikymmenen puolen välin maissa pyrkiä yhteistoimintaan sosialidemokraattien kanssa. Uusi kansanrintamapolitiikka merkitsi sitä, että monet salakommunistit liittyivät sosialidemokraattisiin järjestöihin ja ammattiyhdistyksiin. Osa heistä osallistui myös sosialidemokraattisen kisällitoimintaan, ja näin myös kommunistit omaksuivat kisällilaulunimityksen. Aiemminhan he olivat nimittäneet lauluryh- 
miään propagandisteiksi. 13

Sodan jälkeen kisällitoiminta jatkui jälleen kaksilinjaisena. Sekä sosialidemokraateilla että kommunisteilla oli taas omat nuorisojärjestönsä (Sos.dem. Työläisnuorisoliitto ja Suomen Demokraattinen Nuorisoliitto), ja niissä virisi tuolloin laaja kisällilaululiike: jokaisessa vähänkin aktiivisessa nuoriso- osastossa toimi kisälli- tai kisällitärryhmä, tavallisesti molemmat. Aktiivisimmissa osastoissa jouduttiin perustamaan "ykkös- ja kakkosjoukkueita", koska kaikki halukkaat eivät mahtuneet samaan ryhmään. Lisäksi kisälliryhmiä oli jo 1930- luvulta lähtien Työväen Urheiluliiton järjestöissä ja ammattiosastoissa; sodan jälkeen myös monissa Suomi-Neuvostoliitto seuran osastoissa toimi omia lauluryhmiä. Laajimmillaan kisälliharrastus näyttäisi olleen 1940-luvun viimeisinä vuosina. Esimerkiksi vuonna 1949 kummankin työläisnuorisoliiton osastoissa toimi yhteensä 768 ryhmää, joista kisällitärryhmiä oli $365(48 \%)$. Kun muiden järjestöjen harrastustoiminta lasketaan mukaan, kisälliryhmien kokonaismäärä nousi parhaimmillaan hyvinkin päälle kahdeksan sadan. 14

\section{Kisällien ohjelmistosta}

Kisälliryhmät esittivät kisällilauluja - väite tuntuu luontevalta ja oikealta. Mutta tosiasiassa varsinainen kisällilaulu oli usein vain osa kisälliryhmän ohjelmistoa. Kisällit lauloivat muitakin lauluja. Liittonuoret pyrkivät yleensä erottamaan varsinaisen kisällilaulun muusta lauluperinteestä. $\mathrm{Mm}$. työläisnuorten lehdissä oli 1940- ja 1950-luvuilla monia kirjoituksia, jotka määrittelivät usein varsin normatiivisesti kisällilaulun rajat. Kisällilaulujen tuili sisältää poliittista propagandaa; tekstin tuli olla ajankohtaista, iskevää ja satiirista. Lisäksi ainakin sodanjälkeiseen kisällilauluun kuuluivat välttämättä liikkeet. Kuoromuodostelmassa ja paikallaan laulettua laulua ei pidetty kisällilauluna. Kisällit väittelivät usein myös siitä, voiko varsinaisia kisällilauluja esittää moniäänisesti. Perinteinen propagandalaulu oli tyyliltään karkeaa ja yksiäänistä, mutta toisen maailmansodan jälkeen jotkut ryhmät pyrkivät muuttamaan esitystyyliään moniäänisen kaunolaulun suuntaan. Yksiääninen tyyli jäi silti kisälliryhmien enemmistön laulutavaksi. 1950-luvun puolenvälin jälkeen ainakin neliääniset kvartetit suljettiin kisällilaulukäsitteen ulkopuolelle myös virallisesti - he saivat kulttuurikilpailuissa oman sarjansa ("lauluryhmät"). 15 
Varsinainen kisällilaulu on jaettavissa tekstien sisällön perusteella karkeasti kahteen osaan, (1) poliittisiin hyökkäyslauluihin ja (2) ryhmäsolidaarisuuslauluihin. Poliittisissa hyökkäyslauluissa kisällien satiirisuus pääsi ehkä parhaiten valloilleen. Pekka Gronow $(1976,235)$ on jakanut ne kolmeen tyyppiin sen mukaan, onko laulun aiheena jokin poliittinen henkilö, poliittinen tapahtuma vai puolue. Kaikkia näitä laulutyyppejä sepiteltiin koko kisällilaulukauden ajan. Tekstien tyyli vaihteli aikakauden ja sanoittajien mukaan. Niinpä esimerkiksi 1930-luvun lapualaisvuosina eivät kisällitkään uskaltaneet esittää kovin 'mojovia viisuja', koska pelkäsivät muilutuksia. Lisäksi poliisit saattoivat vaatia kisällien tekstit ennakkotarkastukseen, ennen kuin myönsivät työläisten juhlaan huviluvan. Silti kisällien laulut olivat myös tuolloin kaikkein poliittisin ja satiirisin ohjelmanumero työväen tilaisuuksissa. Vuonna 1938 Vihtori Huhta muisteli kisällilaulun lähihistoriaa: "Jos näissä lauluissa esitettyjä lauseita olisi esittänyt puhuja, olisi hän joutunut autoon, mutta kun ne sanottiin sävelin, niin kansa nauroi ja juhlaan lähetetyt poliisiviranomaisetkin nauroivat". (Huhta mt., 6).

Tilanne oli toinen sodan jälkeen. Nyt myös kommunistit saivat toimia laillisesti ja julkisesti; monet heistä olivat istuneet sodan aikana ja aiemmin vankilassa ja keskitysleirillä ja he olivat tietenkin katkeria edellisten vuosien vallanpitäjille. Katkeruus heijastui myös kommunistikisällien lauluihin. Niiden keskeisenä teemana oli tilinteko - Valkoisen Suomen johtajien päitä vaadittiin sananmukaisesti vadille. Suomen Demokraattisen Nuorisoliiton veteraanit puhuvatkin erityisestä 'verivatilaulujen' ajasta, kun he muistelevat sodanjälkeistä kisällitoimintaa. 16

Sana verivatilaulu antaa aiheen olettaa, että 40-luvun kisälliteksteistä hyppii silmille vertatihkuva koston sanoma. Säilyneet tekstit ovat kuitenkin verraten säyseitä; niissä manataan sotasyyllisille vankilamatkaa ja kuolleille natsijohtajille ikuista helvetin tulta, mutta ei sen jyrkempää. Karmivan verivati-nimityksen ja kesyjen laulutekstien välinen epäsuhta johtunee ainakin kahdesta syystä. Kommunistit elivät omien sanojensa mukaan sodan jälkeen eräänlaisessa "vapauden huumassa", ja lievempikin asioiden suoraan sanominen tuntui kovalta puheelta - hehän eivät olleet voineet arvostella julkisesti mitään asiaa 15 vuoteen. Näin saattoi syntyä harhakuva tosiäkäisten laulujen ajasta. 17

Toisaalta ei ole epäilystäkään, etteikö yksittäisillä ryhmillä olisi ollut myös selkäpiitä karmivia lauluja ohjelmistossaan. Mutta kaikkein kovimmat tekstit olivat lähellä sisäryhmähuumoria. Niitä saatettiin esittää julkisesti, mutta niitä eì tohdittu levitellä muiden ryhmien käyttöön. Näin 
ne eivät koskaan joutuneet keskusjärjestöjen laulukokoelmiin. Mm. helsinkiläiset Toveriseuran kisällit olivat tunnettuja hyökkäävästä esitystyylistään; erityisesti Armas Äikiä kirjoitti heille armottomia hyökkäystekstejä. 18

Hyvän esimerkin Äikiän verivatityylistä tarjoavat hänen runonsäkeensä vuodelta 1943, jolloin Äikiä toimi venäläisten sotapropagandan palveluksessa. Äikiä julkaisi ne Iskelmiä-otsikon alla, mikä sinänsä jo viittaa niiden olevan laulutekstejä. Propagandistityylin mukaisesti ne ottivat tuoreeltaan kantaa päivänpoliittisiin tapahtumiin:

31.4.1943 (Hitler-kopla vietti Saksassa järjestelmänsä 10-vuotisjuhlaa. Natsipäälliköt pitivät juhlapuheita.)

Hitler, Göring, Göbbels, - suotta

natsikopla, vikiset.

Kymmenettä ryöstövuotta

seuraa hetket hikiset.

Sotalaulut pian teiltä

vaimenevat, lakkaavat.

kohta kansat "fyyrereiltä"

päitä poikki hakkaavat.

14.11.1943 (Mannerheimin, "Suomen marsalkan", sanomalehdet julkaisivat kirjoituksia, joissa vakuuttivat Suomen käyvän "erillis"-sotaa, jolla ei ole mitään tekemistä suursodan kanssa.)

Marsalkka nyt pelkää hirttä, sätkyäijää jurnuttaa.

Erillisen sodan virttä

taas tuo konna kurnuttaa.

Eri pää on marsalkalla, eri Aatu paralla.

Eri kirves pölkyn alla

eri päiden varalla.

(Punalippu 5/1975, 126; myös välitekstit lehdestä)

Fasistiset liikkeet ja "kokomusta porvaristo" olivat vuosikymmenestä toiseen työläisnuorten poliittisten ivalaulujen mieliaiheita. Mutta varsinkin 
1940-luvun lopulla ja 1950-luvulla kisällilaulujen perusteemaksi kohosi työväenliikkeen toisen osapuolen mollaaminen - kommunistikisällit tekivät pilkkaviisuja sosialidemokraateista, ja nämä puolestaan asettivat lauluissaan kommunistien toiminnan naurunalaiseksi.

Tämäntyyppiset laulut ovat mainio esimerkki yhdestä poliittisen ryhmäkäyttäytymisen 'peruslaista': lähin poliittinen vastustaja on pahin poliittinen vastustaja, koska se kilpailee saman äänestäjäkunnan kannatuksesta. Työväenliikkeessä tämä on näkynyt kaikkina aikoina; viimeisen parinkymmenen vuoden aikana SKP:n sisäiset kiistat ovat varmasti parhaiten heijastelleet tätä lainalaisuutta.

Mutta 1940-luvun lopun kisällilaulut ilmensivät myös Suomen poliittisen ilmaston muutosta. Ns. kolmen suuren yhteistyö päättyi vuonna 1948, kun kommunistit hävisivät vaalit. SKP joutui tämän jälkeen ulos hallitustyöskentelystä lähes 20 vuodeksi. Sen sijaan sosialidemokraatit olivat monesti hallitusvastuussa ja loittonivat samalla kommunisteista monissa poliittisissa kysymyksissä. Kansainvälisen politiikan kiristyminen - ns. kylmän sodan kausi Neuvostoliiton ja Yhdysvaltain välillä - kiristi osaltaan SKP:n ja SDP:n välisiä suhteita. (Ks. esim. Haataja \& al. 1978, 293-299).

Ivalaulut toista osapuolta vastaan käsittelivät lähes kaikkea mahdollista: työväenluokan "pettämistä", poliittisia "lehmäkauppoja" maalaisliiton ja kokoomuksen kanssa, poliitikkojen väärinkäytöksiä ja korruptiota, puolueiden ulkopoliittisia kytkentöjä (SKP venäläisten agenttina, SDP amerikkalaisten lakeijana) jne.

Jo tuolloin yleisö näyttää olleen hyvin kiinnostunut yksittäisten poliitikkojen vioista ja töppäyksistä - nykyisinhän poliittinen keskustelu ja lehtikirjoittelu on vielä enemmän henkilöitynyttä. Niinpä kisällilaulujen tekijät puuttuivat kärkkäästi julkisuuden henkilöiden henkilökohtaisiin ominaisuuksiin, kuten lihavuuteen, äkkipikaisuuteen, kovaan viinankäyttöön jne. He tekivät sen jopa niin mielellään, että ainakin kommunistinuorten johtajat joutuivat 1950-luvulla varoittelemaan kisälliryhmiä ja sensuroimaan heidän laulujaan, koska ne sisälsivät mm. liian henkilökohtaisia loukkauksia. 19

Myös sosialidemokraatit hallitsivat yksittäisten poliitikkojen panettelun taidon. Seuraava laulu ilmestyi Sos.dem. Työläisnuorisoliiton kisällilaulumonisteessa n:o 45 vuoden 1947 paikkeilla. Siinä kansandemokraattien johtavat naishahmot Hertta Kuusinen, Hella Vuolijoki, Lullan Helo, Kaisu-Mirjam Rydberg ja Sylvi-Kyllikki Kilpi saivat kukin erikseen enemmän tai vähemmän ilkeämielisen luonnehdinnan. 
HAAREMIN HARSOJEN TAKAA...

Sanat: nimim. "Teho"

Sävel: "Poika oli Pohjan Torniosta"

Hertta oli hiukan laihanlainen, sillä lailla tällä lailla laihanlainen.

Hertta oli hiukan laihanlainen, ja valtiksi liian pieni...

Hella oli pyylevä keijukainen, sillä lailla tällä lailla keijukainen.

Hella oli pyylevä keijukainen, mutta pehmyt kuin pesusieni...

Lullanin muodot ne mutkitteli, sillä lailla tällä lailla mutkitteli.

Lullanin muodot ne mutkitteli, ja hän tuoksui kuin Saaronin lilja...

Kaisu-Mirjamin räikeä tyyli, sillä lailla tällä lailla räikeä tyyli.

Kaisu-Mirjamin räikeä tyyli, oli yhtä kuin Riipisen Hiljan...

Sylvi-Kyllikin suuntaviiri, sillä lailla tällä lailla suuntaviiri.

Sylvi-Kyllikin suuntaviiri, se tuulien mukaan vaihtuu...

(Sos.Dem. Työläisnuorisoliiton kisällilaulumoniste $n: 0$ 45, laulussa on yhteensä kahdeksan säkeistöä)

Ryhmäsolidaarisuuslauluja oli lähes jokaisella kisälli- ja kisällitärryhmällä ainakin yksi: oman ryhmän esittelylaulu. Esitys alkoi yleensä tällä kappaleella; siinä ryhmä toi esille nimensä ja viiteryhmänsä; teksti korosti mielellään oman sakin toiminnan reippautta, edistyksellisyyttä ja muuta etevyyttä; myös oma taustajärjestö tuotiin mairittelevassa sävyssä esiin samalla kun poliittisia vastustajia vähäteltiin ja pilkattiin.

Varkauden Tarmon kisällien tunnuslaulu kuvasi urheiluasioita eikä politiikkaa, olihan ryhmän taustajärjestö urheiluseura. Toivo Suomalainen se- 
pitti laulun 1930-luvulla; lainasävelmänä on tunnettu kupletti "Kulkuripoikana maailmalla":

Hei Tarmonpa poekija ollaan
ja huviksemme laaleskellaan!

On perustettu seura meille urheilun malliin

viejäksi eespäin sen aattehen kalliin

ja nimeksi on laetettu Tarmo

ja sen toeminta on melekosen varmoo

Tarmompa poekija on tämä joukko

löyvy ei sakistamme yhtäkään moukkoo

ja meillä on rippeitä poekii

ja kyllä meillä sorkat oekii

Tämän säkeistön jälkeen kisällit esittelivät laulussaan seuransa kaikki toimintamuodot jääpallosta painiin ja penkkiurheiluun yhdeksän säkeistön voimalla. Laulun päättää säkeistö, joka kehoittaa kuulijoita liittymään Tarmoon. Samantapaiseen agitaatiohuutoon päättyivät satojen kisällilaulujen sanat. Propagandan keskeisin tarkoitus oli tehokasta sijoittaa laulun loppuun:

Siksipä työkii nyt liittykee Tarmoo

Myö kaverit ollaa, ol nuor taekka harmoo

ja oeskoha sanottuna suotta

ett' Tarmossa voes ellee sata vuotta!

(Varkauden Tarmon historiikki, Varkaus 1972, 25; laulussa on yhteensä 12 säkeistöä)

Kisällien ohjelmistoon kuului myös sellaisia ryhmäkiinteyttä korostavia lauluja, joissa oli vankka moralistinen pohjasävy. Laulut neuvoivat muun muassa, millainen oli rehti toveri, liittonuoren ihannetyyppi. Oli tavallista, että eri laulut neuvoivat tyttöjen ja poikien käyttäytymistä - esimerkiksi SDNL:n laulukokoelmassa on valistuslauluja tytöille otsikoilla 'Tyttöryhmän laulu', 'Tyttöjen touhuja' ja 'Tämmöiset tytöt', kun taas poikia ohjailtiin lauluilla 'Miehen tie murheenlaaksoon' ja 'Miesihanne'. Toisinaan laulun otsikko oli päivastainen kuin sen sisältö; niinpä 'Laulu tytöille' koh- 
distui kulkureita ja juoppoja miehiä vastaan, ja 'Urheilupoikain laulu' varoitti työläistyttöjä menemästä porvariseuraan, mikäli tytöt halusivat pysyä väleissä reippaiden työläispoikien kanssa. 20

Lauritsalan Meidän Tytöt -ryhmän ohjelmistoon kuului 1950-luvun lopulla laulu 'Miesihanne'. Se kertoo suorin sanoin, millaisista pojista liiton tytöt tykkäävät: ei näöllä väliä, kunhan miehellä oli sopiva jäsenkirja taskussa ja luokkatietoisuutta päässä. Laulu on myös hyvä esimerkki siitä, etteivät amatöörisanoittajien tuotteet aina täyttäneet runousopillisia vaatimuksia. Sanasepoille riitti usein, jos loppusointu oli edes sinne päin: sotilas- saappahat; aina ei riimiä saatu mukaan lainkaan: tulinen - on.

MiesihanNe

Sävel: "Mä meripojast iloisesta laulun tein"

Miesihanne nyt meillä ompi laulun aiheena Nyt saatte sitten kuulla, sekä olla tarkkana. On miehet erilaisia, on monta lajia ja mahdotonta vallan oisi laulaa kaikista.

On paljon tyttöjä, joiden ihanteena on tuo filmitaivaan tähtönen, Don-Juan verraton Hän pitkä sorja ompi vain ja tumma tulinen ja lompakko myös tietysti häll' täyteläinen on.

On paljon myöskin niitä, joita usein miellyttää, tuo sankartyyppi sotainen, vaik' sahajauhopää. Kun on hän sitten poliisi tai palosotilas ja uniformu päällä vain ja kiiltosaappahat.

Mutt' meidän tyttöjä nää eivät miellytä, me emme katso päältäpäin vaan silmistä. Nyt näin saa olla ihanteemme tumma, vaalea kun kovin sotahulluutta hän vaan ei harrasta.

Saa olla laihanlainen, saa olla lihava. Saa olla lyhyt, pitkä, taikka vailla hiuksia. Kun on hän proletaari vain ja luokkatietoinen ja jäsenkirja taskussa on tuttu punainen. 
Ja pojan kanssa tällaisen kun reissailee

ja elonmerta myrskyistäkin seilailee.

Ja määränpää kun molemmill' on yhteinen.

Sen tovereina kuljemme, parempaan luottaen.

(TMI:n Lappeenrantakokoelma)

Tämän laulun tavoin suurin osa moralistisista kisällilauluista kuului nimenomaan tyttöryhmien ohjelmistoon. Muutenkin kisällityttöjen ja -poikien ohjelmistot poikkesivat selvästi toisistaan. Perinteiset sukupuoliroolit rajoittivat tyttöjen repertuaaria suhteellisen paljon. Ohjaajien mielestä heidän ei sopinut laulaa liian ronskeja ja räävittömiä agitaatiolauluja - niitä pidettiin poikien alueena. Käytännössä tämä merkitsi usein, että kisällittärien ohjelmisto oli epäpoliittisempaa kuin pojilla; tytöt tyytyivät esittämään kauniita ja viihteellisiä kappaleita. 21

Myös järjestölehdet pyrkivät ohjaamaan tyttöjen ja poikien ohjelmistovalintoja hyväksyttyyn suuntaan. Terä- lehden 'Laulava sanomalehti' -kirjoitus ilmaisi vuonna 1945 varsin selvästi, mitkä laulut kuuluivat tytöille, mitkä taas pojille:

-- Kun meillä on sekä pojista että tytöistä kokoonpantuja ryhmiä, on välttämätöntä, että heidän numeroissaan on määrätty jako. Varsinainen poliittinen pilkkalaulu, sellainen, jossa humautetaan vastustajaa raskaasti mennen tullen, jäisi varsinaisten poikaryhmien osalle. - - Ei tunnu oikein "mukavalta", jos esim. tuollainen sorjista, kirkassilmäisistä tyttölapsista kokoonpantu ryhmä railakkaasti nyrkkiä heiluttaen uhkaa panna "vastustajan matalaksi". Poikia ikäänkuin paremmin uskotaan tällaisessa tapauksessa. Tyttöryhmien ohjelmistoon sopisivat taasen paremminkin reippaat ja tunnelmalliset nuorisolaulut, innostavat ja sytyttävät taistelulaulut, marssit, naisille omistetut laulut y.m.s. (Anon. 1945a).

Kommunistiryhmien ohjelmistossa oli erityisesti 1950- luvulla myös toinen ivalaulun laji, jossa moralistiset näkemykset paistoivat vahvoina. Näitä lauluja voisi nimittää antiamerikkalaisiksi lauluiksi. Yhdysvallat oli kommunistisen maailman vihollinen numero yksi, ja siitä johtui, että myös SKP:n kulttuuripoliittinen linja oli vahvasti amerikanvastainen. Linjan mukaisesti kommunistinuorten laulunikkarit sepittivät runsaasti kappaleita, jotka irvivät länsimaisen massakulttuurin ja muodin ilmiöitä. Sellaiset laulujen nimet kuin 'Voi muodin oikkuja', 'Länsimaista mallia', 'Laulu purukumista' sekä 'Lättähattulaulu' kertovat jo paljon tämän ohjelmistotyypin sisällöstä. 
Samalla kun kisällit koettivat saada amerikkalaisuuden naurettavaan valoon, he varsin usein moralisoivat myös nuorison tanssivillitystä. Tässä amerikanvastaisuus yhdistyi mielenkiintoisella tavalla työväenliikkeen perinteiseen siveysvalistukseen - monet nuorisokasvattajat olivat jo vuosisadan alussa käyneet kamppailua moraalittomina pitämiään tansseja vastaan, eikä nuorisotyön ideologia ollut vielä 1950-luvulla paljoakaan muuttunut tältä osin. SDNL:n kisällit esittivät lauluja mm. otsikoilla 'Nykyajan tanssit', 'Tanssikuumetta' ja 'Kun tansseissa istuttiin'.22

\section{Ei-kisällilaulut}

Varsinaisten kisällilaulujen lisäksi ryhmien ohjelmistossa oli lähes aina jokin vakavahenkinen, aatteellinen kappale. Tähän luokkaan kuuluivat vanhat työväenmarssit ja muut taistelulaulut sekä rauhanlaulut. Kisällit saattoivat esittää myös kansalaissodan aikaisia vankilalauluja. Näitä kappaleita laulaessaan ryhmä ei tavallisesti liikkunut, vaan seisoi arvokkaassa avorintamassa. 23

Kisällit käyttivät kansanlauluja paljon lainasävelminä, mutta ne kelpasivat ohjelmistoon myös sellaisenaan, alkuperäisillä sanoilla esitettyinä. Kansanlaulut olivat tärkeä ohjelmiston osa varsinkin kommunistikisälleille 1950-luvun puolivälissä. Samat poliittiset syyt vaikuttivat tässä kuin antiamerikkalaisten laulujen esittämisessä. Kommunistinen liike korosti tuolloin voimakkaasti kansallisen kulttuurin vaalimista. Nuorten ohjelmaryhmien tehtäväksi tuli luoda kansanperinteestä vastapainoa länsimaiselle nuorisokulttuurille ja muulle amerikkalaisuuden ihannoinnille. Omana erityisenä ryhmänään olivat venäläiset kansanlaulut ja Neuvostoliiton nuorison laulut. Ne kuuluivat kaikkina aikoina kommunistikisällien ohjelmistoon. 24

Kansanlaulujen esittämisessä näyttää olleen kaksi perustyyliä. Kisällit saattoivat laulaa niitä kaksi- tai useampiäänisinä sovituksina, paikallaan seisten - esitys lähenteli näin kuorolaulua. Toisaalta nopeammat kansanlaulut sopivat hyvin myös liikelauluiksi. Hyvänä esimerkkinä tästä on lauritsalalaisten Meidän Poikien kansanlauluesitys, joka on tallennettu videolle. Ryhmän kappale 'Tupaantulijaiset Tastulassa' sisältää varsin akrobaattisia liikesarjojakin - aitoon kisällityyliin. 25

Vastaavasti kisällit esittivät mielellään vauhdikkaita ja humoristisia kupletteja. Niitä laulaessaan ryhmät käyttivät usein samoja koreografisia 'kikkoja' kuin varsinaisten kisällilaulujen esityksissä.

Oli myös ryhmiä, jotka liikkuivat sulavasti kisällilaulun ja iskelmälaulun välimaastossa. Mikään ei estänyt heitä esittämästä myös päivän muoti- 
iskelmiä, jos iltamayleisö sitä halusi. Esimerkiksi Varkauden sos.dem. nuoriso-osaston kisällittärien bravuurikappaleisiin kuului Georg Malmstenin valssi 'Meidän Maija', muita merimiesvalsseja sekä fokstrotteja. Ryhmä esiintyi samalla ohjelmistolla myös tanssiyhtyeen solistina (Ks. Kurkela 1983, 248-250).

\title{
5. Kisälliryhmän laulun estetiikka
}

\author{
Motto: Mukana oli Mutalan ty:n kisällit - \\ kahdeksan miestä. Lauloimme \\ mojovia viisuja". (Artturi Kiltti, Teisko)
}

Kisällilaulu oli agitaatiota, mutta se oli myös musiikkia. Musiikkina se koostui laulutekstistä, melodiasta, ilmehtimisestä, liikkeistä sekä säestyksestä; viimeksimainittua ei kuitenkaan välttämättä tarvittu. Ilman näitä elementtejä kisällilaulu ei ollut kisällilaulua. Itse laulaminen oli selvästi alisteista tekstiin ja koreografiaan nähden. Mutta silti on tärkeä tietää, miten kisällit lauloivat, minkälaista laulua he pitivät hyvänä ja kauniina. Mikä oli kisällilaulun estetiikka, vai oliko sitä ollenkaan?

Taidemusiikin esteettisen ajattelun rajoissa kisällilaululla oli tuskin estetiikkaa lainkaan. Vaikuttaa siltä, että kisällit lauloivat kaikkien virallisten musiikkinormien vastaisesti. Taidemusiikin näkökulmasta kisällilaulu oli jonkinlaista antimusiikkia; sillä ei ollut esteettistä arvoa.

Mutta kansankulttuurin ja työläisnuorten omasta näkökulmasta tilanne näytti toiselta. Myös kisällilaululla oli oma normistonsa, joka määritteli, millainen laulutapa oli hyvä ja mitä asioita laulussa taas piti välttää. Lienee makuasia, kutsummeko tätä normistoa kisällilaulun estetiikaksi. Amerikkalaisessa etnomusikologiassa on sivuttu samantapaisia ongelmia, kun tutkijat ovat selvitelleet alkuperäiskulttuurien musiikkinormeja. Monet kulttuurit eivät mittaa musiikin arvoa yksinomaan kauneuskäsitteillä - musiikin kauneus saattaa jopa olla tuiki tuntematon käsite. Esimerkiksi musiikin tehovaikutus, musiikin ymmärrettävyys tai musiikin kontekstuaalinen yhteys voi määrätä sen arvon. David McAllester kutsuu tällaisia arvottamistapoja musiikin funktionaaliseksi estetiikaksi (Ks. Herndon \& al. 1981, 172).

Myös kisällilaulun estetiikka oli selvästi funktionaalista. Laulun tärkein tehtävä oli tuoda poliittinen sanoma mahdollisimman tehokkaasti yleisön tietoisuuteen. Teiskolaisen Artturi Kiltin sanoin tämä tarkoitti 
"mojovien viisujen" laulamista. ${ }^{26}$ Hiilipojat-kisälliryhmän jäsen ja ohjaaja Ahti Nieminen kuvasi perinteistä laulutapaa seuraavalla tavalla:

-- Se oli - - mahdollisemman voimakasta ja ihmistä, kuulijaa suggeroivaa. Teksti meillä oli aina hyvin tärkeä, että se tuli hyvin selvästi lausuttua ja siihen tehtiin aika paljon töitäkin. Mutta voimaa olis saanu kyllä tietysti - kun puhutaan kauneudesta toisessa mielessä - ni vähentää. Sillä (laululla) pyrittiin julistuksenomaiseen - efektiin. Ja kun nyt ryhmä laulaa oikein pontevasti, sen näkee suoraan sieltä estraadilta, että nuo kaverit on sillä asialla. Ja kun kuulijakunta on samalla aaltopituudella ja kun siihen tulee aplodit väliin, ni se vieläkin ehkä siitä kovenee ja voimistuu sitten. Että siihen tulee vähän semmone julistamisen ja huutamisen maku. Mutta se kuulu sillon niinku siihen asiaan. (TMIc 1983-9:16.)

Tärkeintä kisällien laulussa oli siis voimakkuus ja sanojen selkeys. Niemisen mukaan esimerkiksi puhtaassti laulaminen ei ollut tyylin kannalta lainkaan olennaista - hyvä ryhmä kykeni tempaamaan yleisön mukaansa ilman sitäkin. Monien ryhmien laulu lähentelikin karkeaäänistä huutoa; sitä voisi kuvata huonosti yhteensointuvaksi unisonolauluksi, joka saattoi sisältää melodisten epätarkkuuksien vuoksi myös heterofonisia kohtia. Rytmisesti laulun tuli ilmeisesti olla melko täsmällistä, koska tekstin selkeä lausuminen edellytti sitä. Säestyssoitin auttoi tässä asiassa; se myös ohjasi pahimmat pieleenlaulajat kohti korrektia melodiaa.

\section{Kisällit ja kaunolaulun ihanne}

Kisällilaulua ohjasi omaperäinen, kansanomainen normisto. On kuitenkin selvää, ettei tämäntapainen funktionaalinen estetiikka voinut olla sopusoinnussa työväenliikkeen taiteellisen musiikkitoiminnan kanssa. Työväen kuoro- ja orkesteritoimintaa ohjasi Suomen Työväen Musiikkiliitto (STM), joka oli perustettu 1920. Liitto pyrki alusta saakka kehittämään työläisten musiikkiharrastusta taiteellisesti arvokkaaseen suuntaan, ja tämän arvokkuuden mittapuuna oli tietenkin taidemusiikin esteettinen traditio. Näin STM oli osa musiikillista kansanvalistusliikettä. (Esim. Hurri 1982, 19, 28).

Sitä mukaa kun kisällilaulu sai yhä näkyvämmän aseman työväenliikkeen iltamissa ja juhlissa, STM:n johtohenkilöt alkoivat osoittaa hermostumisen merkkejä. "Kuka tietää, kuinka suuren sijan kisällilaulu valloittaa juhliemme ohjelmissa syrjäyttäen neliäänisen kuoromusiikin toisarvoiseen asemaan", kyseli Työväen Musiikkilehden pääkirjoitus vuoden 1936 alussa (Anon. 1936, 23). Vuotta myöhemmin saman lehden pääkirjoitus katsoi 
parhaaksi muistuttaa iltamajärjestäjiä siitä, että "kisällilaulun ja jazzmusiikin varassa ei kohoteta työväen henkistä tasoa". "Kisällilaulajien usein jopa ala-arvoiset esitykset", lehti lisäsi, "eivät suinkaan kohota juhliemme arvoa puhumattakaan siitä, että niillä saatetaan kasvattaa juhliemme yleisöä vakavampaa ja taiteellisesti pätöisempää kuoromusiikkia vieroksuvaksi." (Anon. 1937, 27).

Liiton huoli kisällilaulun rappiovaikutuksesta tuntuu jälkikäteen ehkä yliampuvalta. Mutta STM:n johdolla oli vuonna 1937 tuoreessa muistissa toinen 'rappiomusiikin' uhka, joka oli käynyt toteen: tanssimusiikin murros oli muutamaa vuotta aiemmin osoittautunut varsin kohtalokkaaksi työväen soittokunnille. Uudentyyppiset 'jazzorkesterit' olivat syrjäyttäneet ne iltamien musiikkitarjonnassa, ja moni soittokunta kärsi soittajapulasta ellei ollut joutunut kokonaan lopettamaan toimintaansa.27

Edes kaikkein kiivaimmatkaan musiikkikasvattajat eivät voineet STM:ssa täysin mitätöidä kisällilaulun merkitystä - sen poliittinen painoarvo oli liian suuri. Mutta musiikillisesti kisällilaulu oli heille ilmeisen vastenmielistä. Em. pääkirjoitus jatkoi:

-- Kisällilaulut sinään eivät suinkaan ole kaikkea merkitystä vailla juuri vakavan ohjelman höysteenä, mutta ne eivät saa rakentua halpahintaisiin sanakäänteisiin, eikä niihin missään tapauksessa ole lainattava tunnettujen laulujen sävelmiä, jotka huonosti esitettynä ja sävelelle vieraaseen tekstiin sovitettuna tuntuvat suorastaan loukkaavilta. (Anon. 1937, 27).

Erityisen kiintoisaa tekstissä oli se, että kirjoittaja tuomitsi lainasävelmätekniikan. Kisällilaulun keskeisin taiteellinen periaate oli ilmeisessä ristiriidassa kirjoittajan esteettisen näkemyksen kanssa. Ainakin osa työväenliikkeen sivistysjohtoa jäi samalla tavoin täysin kisällilaulun musiikkimaailman ulkopuolelle. Heille tämä laulu oli tuskin musiikkia lainkaan, vaikka he saattoivatkin hyväksyä sen tehokkaana agitaatiomuotona.

Mutta työläisten taidekasvattajien joukossa oli myös niitä, jotka suhtautuivat ymmärtävämmin kisälliperinteeseen. He näkivät uudessa laulumuodossa jalostamiskohteen: kisällilaulajat oli johdatettava musiikkioppiin. Vihtori Huhta kirjoitti vuonna 1938 Työväen Musiikkilehteen selkeän jalostusohjelman:

-- Kisällilaulut ovat kaikesta alkeellisuudestaan huolimatta plussaa meidän aatteellisille kulttuuriharrastuksillemme - - Kunhan ne saataisiin aikojen kuluessa vielä sellaisiksi, että niitä voitaisiin esittää kuorolauluina, johdettuina, niin olisi astuttu oikea konkariaskel eteenpäin. Harkitkaapas te, Musiikkiliittomme johtavat pamput, 
olisiko tätä asiaa autettavissa esim. siten, että liiton kursseille otettaisiin yhdeksi "ohjelmanumeroksi" tämän uuden aatteellisen "epidemian" johtaminen taiteellisille urille. (Huhta mt,. 7).

Taiteellisille urille johtaminen tuli tarkoittamaan lähinnä sitä, että sodan jälkeen kisällilaululiikkeessä ilmeni pyrkimyksiä muuttaa laulutapaa moniääniseksi. Selvemmin tällaiset pyrkimykset näkyivät sosialidemokraattisen nuorison keskuudessa. Asiaan saattoi vaikuttaa se, että STM:n musiikkikasvattajat olivat lähempänä sosialidemokraatteja kuin kommunisteja.28

Myös Vihtori Huhta jatkoi kisällilaulun jalostamisvaatimuksiaan. Vuonna 1948 hän valitti Työläisnuoriso-lehdessä, että kisällilaulua vaivasi yhä vaan "valitettava heikkous, - - nim. se, että ne lauletaan yksiäänisesti". Kirjoittaja kehoitti ryhmiä etsimään joukkoonsa edes yhden "tarkkakorvaisen", joka kykenisi laulamaan toista ääntä. "Mikä hivelevä vaikutus sillä olisi kuulijan korvaan!", Huhta vakuutteli lukijoitaan. (Huhta 1948).

Huhdan toive oli saanut jo vähän tuultakin alleen Työläisnuorisoliitossa. Järjestön ensimmäisissä sodanjälkeisissä liittojuhlissa laulukilpailun voitti kisälliryhmä, jonka ansioita liiton lehti kuvasi näin:

-- Kisällien ensimmäisen paikan määrääminen olikin vaikeampaa kuin kisällittärillä, mutta sellaiset ratkaisevat tekijät kuin kaksiääninen laulu ja ilman säestystä laulaminen olivat luonnostaan lankeavaa plussaa voittajajoukkueelle. - - On opittu paljon ja kisällilaulun tie kohti "arvosanaa" t a i d e on alkanut. (A. ja o. 1945, 2)

Uusi estetiikka oli näin tunkeutunut kisälliharrastukseen - voittajaryhmän laulutyyli poikkesi selvästi perinteisestä agitaatiotyylistä. Mutta kaikki eivät olleet uudistuksen kannalla. Niinpä Työläisnuoriso-lehden toimittaja Olavi Hurri tiesi viisi vuotta myöhemmin kertoa, kuinka arvostelutuomarit olivat jättäneet moniäänisesti laulavat kisällit kulttuurikilpailujen hännille. Tuomarien mielestä kunnon kisälliryhmä ei saanut laulaa kaksiäänisesti. (Hurri 1950, 2).

Kysymys taiteellisemmasta kisällilaulusta puhutti sosialidemokraattisia kisällejä ja heidän ohjaajiaan vielä pitkään. Lehtikeskustelusta voi erottaa kaksi 'koulukuntaa', propagandistit ja uudistajat. Edellinen ryhmä puolusti kisällilaulun funktionaalista estetiikkaa: laulun tuli palvella ensisijaisesti agitaatiotarkoitusta; tekstin iskevyys, liikkeiden vauhdikkuus ja yhtenäisyys olivat heidän mielestään paljon tärkeämpiä kuin lauluosuuden taiteellinen jalostaminen. Esimerkiksi STN:n Vaasan piirisihteeri Niilo Haaranen epäili syksyllä 1948, että kaksiäänisessä laulussa esiintyjien piti keskittyä niin paljon itse laulamiseen, että se kahlitsi koreografiaa. (Haaranen 1948, 6). 
Myös liittosihteeri Uuno Nokelainen vastusti moniäänistä kisällilaulua, sillä se ei ollut hänestä enää mitään kisällilaulua:

-- Uudistajat väittävät kehittävänsä kisällilaulua tuomalla sen piiriin moniääniset laulut. Itse asiassa he kuitenkin tällöin juuri heittävät pois erään kisällilaulun tärkeimmistä erikoispiirteistä, liikkeet, jotka juuri erottavat kisälliryhmän muusta lauluryhmästä. - - Kisälliryhmä on silloin muuttunut kuoroksi, mikä taas on aivan asia erikseen. (Nokelainen 1950, 7).

Uudistajat puolestaan katsoivat, että vanha propagandalaulu oli jo aikansa elänyttä. He halusivat viedä esityksiä uusille raiteille, ja moniääninen laulu tarjosi tähän yhden mahdollisuuden. Myös liikkeet oli mahdollista sovittaa uuteen lauluun. Kisällilaulaja Kauko Toivonen vastasi Nokelaisen kirjoitukseen. Hän korosti uuden laulutyylin suosiota ja sen kasvatuksellista merkitystä:

-- Nykyisin moniäänisissäkään lauluissa ei jäädä seisomaan pilareina. Lisäksi on todettu kaksiäänisyys + liikkeet yleisöönmenevimmiksi. - - Moniäänisyyden vaatima sitkeä harjoittelu on omiaan kiinteyttämään ryhmän työtä, kehittämään laulajia, edistämään näiden sopeutumista toisiin jne. Tällä tavoin moniäänisyydestä on muodostunut merkittävä kasvatuksellinen tekijä. (Toivonen 1950, 7).

Toivosen kirjoituksesta ilmeni myös se, että kysymys laulutyylistä oli samalla myös kysymys kisällilaulujen sisällöstä. Uudistajat halusivat selvästi laajentaa repertuaaria - he tahtoivat "tarjota yleisölle myös satiiria ja leikillisyyttä ilman verenkarvaista aatteellisuutta". Liika poliittisuus vain väsytti yleisöä, Toivonen todisteli.

Propagandistien ja uudistajien musiikkinäkemys oli siten jo lähtökohdiltaan erilainen. Propagandisteille laulutyyli ja itse asiassa koko kisällilaulukin oli välineellistä toimintaa. Sen ensisijainen tehtävä oli tukea poliittista työtä ja aatteellista kasvatusta. On oireellista, että juuri työläisnuorten poliittiset johtajat - liitto- ja piirisihteerit - ajoivat tätä linjaa. Heille poliittinen työ merkitsi huomattavasti enemmän kuin musiikkiharrastus.

Uudistajat olivat käytännön musiikkimiehiä, lauluntekijöitä ja laulajia. He olivat myötämielisempiä virallisen musiikkikasvatuksen päämääriä kohtaan. Heille kisällilaulu ei merkinnyt ainoastaan poliittista julistusta. He halusivat kehittää sitä myös taiteellisesti. Tosin tämä halu jäi käytännössä perin verbaaliselle tasolle. Myös kisällikauden loppuaikana suuri osa ryhmistä esitti laulunsa yksiäänisesti. 29

Kun kommunistit käynnistivät kisällitoimintansa sodan jälkeen, ei kysymys laulutyylistä nostattanut juuri keskustelua. Ryhmät koottiin 1920- 
luvun propagandistiryhmien perinteelle, joten laulutyylikin oli karkeaa ja agitoivaa. Niinpä Terä-lehden ensimmäinen kisällilaulujuttu vuonna 1945 asetti kisällien laululle varsin matalat taiteelliset tavoitteet. Lehden mukaan ryhmiin oli pyrittävä valitsemaan henkilöitä, joilla oli "jonkinlainen lauluääni ja tarkka sävelkorva". Tekisihän kiusallisen vaikutuksen, jos joku joukosta vetäisi koko ajan "omaa sovitustaan". Tarkka sävelkorvakaan ei ilmeisesti ollut aivan ehdoton vaatimus - yhtä tärkeää oli esimerkiksi laulajan ulkonäkö. Heti perään jutun kirjoittaja neuvoikin ryhmiä valitsemaan joukkoonsa "etupäässä nuoria, mikäli mahdollista hauskan näköisiä laulajia". Lehden mukaan kaksiäänistä laulua kannatti silti "joskus" kokeilla, sillä se antoi "hyvän säväyksen" (Anon. 1945a; 1945b)

Silti esteettinen musiikkivalistus ei jättänyt kommunistinuoriakaan osattomiksi. Jo vuonna 1948 SDNL:n kisällien pääohjaaja Reino Sandell kannusti ryhmiä moniääniseen lauluun:

-- Kisälliryhmä voi laulaa moniäänisesti, mutta elävästi, liikkeillä ja hauskoilla ilmeillä lauluaan tehostaen. Kun tähän päästään, olemme lähellä täydellisyyttä. Siis älkää luopuko moniäänisestä laulustanne... (Sandell 1948).

Mutta myös kommunistikisällien moniääninen laulu jäi lähinnä lehtikirjoitusten ja ohjeiden tasolle. Käytännön harrastus jatkui etupäässä yksiäänisenä, eikä laulutaito ollut kisälliharrastuksen keskeisin asia. Silti monet ryhmät yrittivät parannella esityksiään "soinnutteluilla", jotka olivat useimmiten ryhmän omasta päästä. Tämä ei välttämättä kuulostanut ohjaajien mielestä kovin hyvältä. Niinpä SDNL:n julkaisema ohje kisällilaulujen esittämisestä oli ottanut 1950-luvun lopulla jo toisen kannan: sen mukaan "hyvin laulettu yksiääninen esitys on huomattavasti parempi kuin heikko soinnutteluyritys". 30

Oli silti joitakin ryhmiä, jotka pystyivät kehittämään laulutyylinsä uuden estetiikan mukaiseksi. SDNL:n Hiilipojat-ryhmä oli näistä ehkä kaikkein tunnetuin. Ryhmä lauloi ensin vanhatyylisiä kisällilauluja, mutta 1950-luvun puolen välin jälkeen sen tyyli muuttui nopeasti. Ryhmän jäsenet alkoivat opetella äänenmuodostusta taidemusiikin ammattilaisten johdolla. Ahti Nieminen kertoo, kuinka koko ryhmä sosiaalistui kaunolaulun maailmaan:

-- Kun laulua tuntevat ihmiset ja musiikki-ihmiset pääsivät puuttumaan meidän tapaamme esiintyä ja laulaa, - - niin myöskii kavereille tuli ihan, ihan toisenlainen fiilis siihen asiaan tai toisenlainen tarkotus siihen asiaan. Ja tälläset Ruhasen Oivat ja Onni Kelot ja monet muut kaverit, muun muassa Kivilahden Kosti - - monta kertaa sanoivat, että tuon vois tehdä ja lauletaan se kauniimmin toi homma. Ja se tarttu 
vaatteisiin ja sitä funtsattiin itse ja sitten todettiin että asia todella on näin. (TMIc 1983-9:16)

Hiilipoikien uusi tyyli läheni kvartettilaulua. Huomattavaa on, etteivät he itsekään pitäneet esityksiään enää kisällilauluina. Esimerkiksi kulttuurikilpailuissa he lauloivat 'lauluryhmä'-sarjassa eivätkä kisällisarjassa. Uusi estetiikka synnytti uuden perinteen, jota toiset kisälliryhmät yrittivät sitten jäljitellä. Tämä olisi kuitenkin vaatinut ammattimaista ohjausta. Kisälliryhmien enemmistö ei kyennyt lyhyiden harrastajakurssien turvinkaan seuraamaan Hiilipoikien kipparikvartettityyliä. Eikä heidän tarvinnutkaan sehän ei ollut enää kisällilaulua.

\section{Järjestölaulu ja kurinalaisuus}

Kisällilaulussa oli monia piirteitä, jotka saivat sen näyttämään tyypilliseltä folklorelta. Dan Ben-Amosin esittämää folkloren määrittelyä soveltaen voi sanoa, että kisällilaulu oli pienyhteisön musiikillista viestintää (Ben-Amos 1972, 9-13). Sen esittäjät olivat saman yhteisön jäseniä kuin kuulijat. Siinä oli lisäksi paljon samoja ominaisuuksia kuin vanhemmassa kansanmusiikissa: se ei yleensä perustunut nuottisoittoon; se oli amatöörimäistä ja funktionaalista (se ei ollut taidetta taiteen vuoksi); se noudatti kansankulttuurin musiikillisia intonaatioita sekä heijasti yhteisön omaksumaa maailmankuvaa ja ideologiaa.

Mutta toisaalta kisällilaulu oli erilaista, se oli järjestömusiikkia. Se liittyi kiinteästi työläisnuorten yhdistystoimintaan. Tämä ei voinut olla heijastumatta kisällilaulun olemukseen. Järjestösidonnaisuus oli ratkaiseva tekijä, joka erotti kisällilaulun vanhemmasta folkloresta.

Työväenmusiikin tutkimuksen klassikko Wolfgang Steinitz on kuvannut sitä muutosta, jonka yhdistystoiminta aiheutti kansanjoukkojen musiikissa. Hänen huomionsa auttavat meitä ymmärtämään kisällilaulua työväen musiikkitoiminnan osana. Steinitz vertasi järjestäytyneen työväenliikkeen uusia lauluja vanhempaan työväenlauluun. Saksalainen työväenlaulu koostui tämän vuosisadan alussa kahdesta perinteestä, (1) taiteellisista kuorolauluista, jotka olivat lähellä taidemusiikkiperinnettä ja levisivät nuoteilla varustettujen laulukirjojen avulla sekä (2) työväenhenkisistä kansanlauluista (Arbeitervolkslieder), jotka välittyivät kuten kansanperinne yleensäkin pääasiassa korvanvaraisesti ja varioiden. (Steinitz 1962, XxIII-XXVII).

Steinitz huomasi, että työväenliikkeen laulukirjoissa oli vain ensinmainittuja lauluja. Ne olivat työväenliikkeen uutta järjestöperinnettä. Nii- 
den ja kansanlaulun tapaan leviävien laulujen välillä oli "laadullisesti olennainen" ero. Niiden kulkeutumista valvoi tiukka järjestelmä; perinteen välittyminen oli siten ylhäältäohjattua. Myös musiikin tekijät olivat muuttuneet. Kun kansanlaulun perinteenkannattajat koostuivat tavallisesta rahvaasta, järjestömusiikin tekijät oli monesti uutta sivistyneistöä, kuten toimittajia, työläiskirjailijoita, kuoronjohtajia ja teatteriohjaajia (Ibid.). $\mathrm{He}$ kuuluivat siis siihen työväenkulttuurin osaan, jota etnologi Flemming Hemmersam kutsuu työväen johtajien perinteeksi. (Hemmersam 1979, 7881).

Näillä järjestöjen perinteenkannattajilla oli omat normistonsa, jotka ohjasivat laulujen sepittämistä, julkaisemista ja levittämistä. Heidän näkemyksen oli lähellä taidemusiikin estetiikkaa mm. siinä, etteivät he hyväksyneet vapaasti muuntuvia lauluja; päinvastoin, hyvällä ja kelvollisella laululla oli oltava tarkasti määritelty muoto ja rakenne. Sitä ei esittäjien sopinut mennä muuttelemaan. (Steinitz ibid.; vrt. Heimann 1977, 205-206).

Työväenliikkeen poliittisessa elämässä syntyi silti koko ajan paljon taistelulauluja, jotka levisivät vanhemman kansanlaulun tapaan. Ne olivat suosittuja ja niillä oli tärkeä asema työväen järjestötoiminnassa. Ne eivät tietenkään täyttäneet järjestömusiikin tekijöiden esteettisiä vaatimuksia. Mutta työväenjohtajat pitivät niitä poliittisesti hyvin arvokkaina. Steinitzin kirjassa on hyviä kuvauksia siitä, kuinka kustantajat päättivät pitkien pohdintojen jälkeen ottaa niitä laulukirjoihinsa: aatteellinen tarkoituksenmukaisuus päihitti esteettisen epäluulon. (Steinitz mt., XXI-XXII).

Steinitz ei asiaa käsittele, mutta on selvää, että myös kansanlaulunomaiset työväenlaulut menettivät muuntumiskykynsä, kun ne painettiin ja nuotinnettiin kirjoihin. Samalla järjestöjen omat musiikilliset käytännöt määräsivät myös kappaleiden esitystyylin entistä tarkemmin. Järjestömusiikki oli omaksunut uudenlaisen kurinalaisuuden idean, joka oli vieras kansanomaiselle musiikille. Nyt myös poliittisesti tärkeät kansanomaiset laulut joutuivat yhtenäistävän esityskäytännön piiriin.

Suomalainen kisällilaulu on tyyppiesimerkki kansanomaisesta musiikista, joka oli poliittisesti tärkeää ja josta sen vuoksi tuli järjestömusiikin keskeinen osa. Kurinalaisuuden idea näkyi myös sen kehityksessä. Se heijastui kisällien ohjelmistossa ja esitystyylissä yhtenäisyytenä, jopa kaavanún isuutena. Yhtenäisyyden takeena oli se, että yksittäiset ryhmät olivat sangen riippuvaisia keskusjärjestöjen ohjauksesta.

Erityisen selvästi tämä vaikutti kisällien repertuaariin. Ryhmien ohjelmistot olivat usein peräisin erityisistä katto-organisaatioista: 1920-luvun propagandisteilla oli ohjelmistopalvelua varten erityinen Helsprokeskus. Sos.Dem Työläisnuorisoliitto julkaisi vuodesta 1930 lähtien säännöllisesti kisällilaulumonisteita, jotka sisältivät yleensä kymmenkunta 
laulua. Liitto lähetti niitä paikallisosastojensa kisälliryhmille ympäri maata 2-3 kappaleen vuosivauhtia - vuoteen 1950 mennessä monisteita oli ilmestynyt jo yli 50. Sodan jälkeen kommunistinuorten järjestö SDNL perusti erityisen Valistuskeskuksen, joka ohjasi liittonuorten ohjelmatoimintaa ja välitti materiaalia. Myöhemmin keskuksen nimi muuttui Ohjelmatyöksi. Tämä organisaatio tuotti ja välitti kisällitekstejä osastoille vähintään yhtä aktiivisesti kuin sos.dem. nuorten liitto. Laajin säilynyt Ohjelmatyön laulukokoelma on vuosilta 1946-1960. Se käsittää yhteensä 619 laulua; näistä varsinaisia kisällilauluja on 532. Huomattava osa Ohjelmatyön lauluista on kuitenkin irrallaan eri paikoissa. Osa on kokonaan hävinnyt - päivänpoliittisilla lauluilla ei ollut käyttöä myöhemmin, eikä ryhmillä ollut mitään tarvetta säilyttää niitä.31

Tehokkaasta ohjelma-avusta johtui, että kisälliryhmät ympäri maata lauloivat usein samoja lauluja. On tosin huomattava, että tämä koski vain 'tavallisia' ryhmiä, kisällien suurta enemmistöä. Parhaimmat ja vireimmät ryhmät tekivät laulunsa itse tai käyttivät 'hovirunoilijoita'. SDNL:ssä tällaisia porukoita olivat mm. Hiilipojat, Toveriseuran kisällit, Porin kisällit ja Kemin Yöjuoksijat. Tavallaan nämäkin ryhmät yhdenmukaistivat kisälliperinnettä: huomattava osa huippuryhmien lauluista kulkeutui järjestökanavia myöten koko kisällikunnan käyttöön. 32

Ohjelmiston lisäksi keskusjärjestöt lähettivät ryhmille esiintymisohjeita. 1930-luvulla ohjeet kulkeutuivat laulutekstikokoelmien mukana; sodan jälkeen ohjeet välittyivät järjestölehtien avulla. Terässä ja Työläisnuorisossa (vuodesta 1952 Kiuru) ilmestyi lähes joka vuosi kirjoituksia tai keskustelusarjoja, joissa kisällien ohjaajat ja nuorisojohtajat ilmaisivat käsityksensä oikeasta esitystyylistä, ohjelmistosta ja kisällilaulun merkityksestä.

Usein nämä kirjoitukset ilmestyivät työläisnuorten kulttuurikilpailujen jälkeen. Ryhmien väliset kilpailut olivatkin 1940- ja 1950-luvuilla tärkeitä tapahtumia kisälliharrastuksen kannalta. Tällaiset kilpailut kuuluivat olennaisena osana työläisnuorisojärjestöjen piiri- ja valtakunnanjuhliin, joita pidettiin vuosittain. Lisäksi monet kunnat järjestivät kulttuurikilpailuja erilaisten nuorisojärjestöjen jäsenille, myös kisälleille. Huomattava kilpailujen järjestäjä oli noina vuosina myös SNE, Suomen Nuorisojärjestöjen Edustajisto. Se perustettiin vuonna 1946, ja sen keskeisenä tehtävänä oli järjestää muutaman vuoden välein (vuodesta 1949 lähtien joka neljäs vuosi) kulttuuritapahtumia järjestönuorille. Nämä "nuorison kulttuurivuodet" huipentuivat ohjelmaryhmien ja yksittäisten taiteenharrastajien valtakunnallisiin kilpailuihin. Kisälli- ja kisällitärryhmiä oli mukana alusta alkaen. 33

Kilpailut innostivat ja lisäsivät kisällien lauluharrastusta. Mutta niillä 
oli myös selvä yhtenäistävä vaikutus. Kilpailujen tuomaristo koostui tavallisesti tunnetuista kisälliohjaajista ja musiikkimiehistä. Heillä oli varsin vakiintunut käsitys siitä, millaista hyvän kisällilaulun tuli olla ja millaista se ei saanut olla. Esimerkiksi täysin epäpoliittista viihdettä esittävät ryhmät saattoivat tippua palkintosijalta, samoin liian paljon tai liian vähän liikkuvat ryhmät, vaikka heidän esityksensä muuten olisi ollut huipputasoa. On ilmeistä, että ryhmät pyrkivät menestyksen toivossa lukemaan hyvin tarkasti tuomareitten lausuntoja kilpailujen jälkeen ja noudattamaan niitä jatkossa. 34

Työläisnuorisoliitot järjestivät myös ns. ohjelmatoimintakursseja, joissa kisällilaulajat, lausujat ja tanhunharrastajat saivat opastusta harrastuksessaan. Myös nämä kurssit yhdenmukaistivat kisälliperinnettä. Kursseille oli usein kutsuttu harrastajia eri puolilta maata olevista osastoista. Kunkin osallistujan tehtävänä oli välittää saamansa opit oman osastonsa muille harrastajille. On vaikea sanoa, olivatko ohjaajat liian autoritaarisia vai järjestönuoret liian kuuliaisia, mutta joka tapauksessa nuoret omaksuivat kurssin opetuksen yleensä ilman pohdintaa, matkimalla orjallisesti ohjaajien ratkaisuja. Esimerkiksi SDNL:n kisällien ohjaaja Ahti Nieminen kertoo, kuinka liittonuoret veivät tavallisesti kurssien malliesitykset sellaisenaan osastoihinsa ja opettivat ne piiruakaan muuttamatta omille ryhmilleen. Nieminen saattoi myöhemmin tavata kilpailuissa lukuisia ryhmiä, joista jokainen esitti hänen malliohjelmansa täsmälleen samalla tavalla, täsmälleen samoja liikkeitä ja tehokeinoja käyttäen. (TMIc 1984-9:19).

Myös Kosti Kivilahti, eräs tunnetuimmista lauluntekijöistä oli pahoillaan liittonuorten mielikuvituksen puutteesta. Hän selvitteli asiaa Pekka Gronowille 1960-luvun lopulla kovin sanoin:

-- Mitä helvetin ätyä on kursseilla jolla opetetaan joku muutama uus kisällilaulu ja tehdään niihin sitten tuommoset helvetin marionettiliikkeet. Sitten niitä näkee joka puolella Suomee samanlaisin liikkein vedettynä - saatana siis ihmiset ei millään tavalla viitti vaivaa mielikuvitustaan eikä tehdä mitään omaa. (TMId 1983-2:1).

Yhdenmukaisuuden idea heijastui myös kisälliryhmien kokoonpanoihin. Jo 1920-luvulta periytyi kisällilauluun ehdoton sukupuolijako. Sekaryhmiä ei suvaittu, vaan osastojen oli perustettava poikia ja tyttöjä varten erilliset ryhmät. Aiemmin jo kuvasin, kuinka sukupuolijako ja perinteiset käsityksen miehen ja naisen rooleista heijastuivat itse ohjelmistoon: karskit laulut olivat poikia varten, hempeämmät viisut sopivat paremmin tytöille.

Ehkä kaikkein selvimmin kisälliperinteen kaavamaisuus näkyi ryhmien koreografiassa. Ilmeisesti liikkeet eivät edes kuuluneet alkuaikojen kisälliesityksiin - ainakin sosialidemokraattinen muistitieto kertoo, että kisäl- 
liryhmät omaksuivat koreografian vähitellen 1930-luvun kuluessa. Tapanilan Hyrskynmyrsky oli liikkeiden kehittelyssä edelläkävijäryhmä. Osa ryhmän jäsenistä oli näyttelijöitä, mikä osaltaan saattoi helpottaa näyttämöllisen liikehdinnän kehittämistä. 35

Sodanjälkeisinä vuosina liikkeet olivat jo erottamaton osa kisällilaulua. Vuonna 1948 Sos.dem. Työläisnuorisoliiton sihteeri Tapio Manninen kuvasi kisällien koreografiaa ja jakoi sen kolmeen pääsuuntaan:

-- On ryhmiä - varsinkin kisällitärryhmiä - joiden jäsenet esiintyvät jäykkinä ja liikkumattomina sekä toisia, joissa jokainen esiintyjä pyrkii tekemään lauluun sijoitetut kumarrukset, taivutukset ja yleisesti kädennykäisyt koneellisesti samaan aikaan ja samalla tavoin aivankuin amerikkalaisessa baletissa sekä lopuksi kolmas tyyli, jossa pyritään miltei kuvaelmantapaiseen liikuntaan tai laulun aiheisiin liitettyjen "pyramedioiden" rakenteluun. (Manninen 1948, 3).

Mannisen 'luokittelun' toinen tyyppi muodosti kisälliperinteen yleisimmän koreografian. Ensimmäinen suuntaus ei voinut sodan jälkeen enää olla kovin yleinen, sillä paikallaan seisovaa ryhmää ei enää pidetty oikeana kisälliryhmänä. Tällä tyylillä ei voinut menestyä esimerkiksi kilpailuissa. Mannisen kuvaama kolmas tyyli viittaa selvästi työväenliikkeen voimisteluperinteeseen - ihmispyramidien teko kuului vuosisadan alkupuolen iltamien ja juhlien vakionumeroihin. Tämä yliliikunnallinen tyyli ei myöskään saavuttanut laajempaa suosiota, ainakaan siitä ei ole säilynyt mainintoja lehdissä eikä muistelmissa.

Pitäytyminen täsmällisissä, konemaisissa liikesarjoissa johtui osittain siitä, että kisälliohjaajien enemmistö oli säännöstellyn koreografian kannalla. Monissa lehtijutuissa kisällejä varoitettiin laajoista liikesarjoista, sillä kirjoittajat katsoivat niiden hajoittavan esityksen kokonaisuutta ja vaikeuttavan laulua. Liikkeille määriteltiin myös varsin tarkat rajat, kuten katkelma Terä-lehdestä vuodelta 1945 osoittaa:

-- Se "elintila", joka jokaiselle laulajalle tässä tapauksessa olisi suotava, rajoittuisi kai käsiliikkeissä sille alueelle, minkä kyynärvarsi kykenee heilumaan silloin kun itse käsivarsi ei huomattavammin kohoa tai erkane vartalosta (Anon. 1945a).

Ohjeen hengen mukaisesti kisällien koreografia kehittyi sangen vähäeleiseksi. Laulajat eivät huitoneet ja hosuneet koko lavan alueella, vaan seisoivat esimerkiksi kaarimaisessa avorivissä yleisöön päin. Säestäjän paikka oli ryhmän sivulla siten, ettei yleisön huomio juuri kohdistunut häneen. Ryhmän liikkeet olivat tavallisesti pieniä ja täsmällisiä. Yleensä kaikki laulajat tekivät liikkeet yhtä aikaa - välissä saattoi olla jokin soolo- 
osuus, jota muu joukko myötäili. ${ }^{36}$

Ryhmät menivät yhtenäisyydessä nähtävästi niin pitkälle, ettei se enää tyydyttänyt ohjaajien tyylitajua. Niinpä esitysohje SDNL:n kisälleille tiesi 1950-luvulla varoittaa, etteivät ryhmät "saisi rajoittua konemaisiin yhteisliikkeisiin, vaan pitäisi mahdollisimman paljon oppia myös itse ilmehtimään sekä antamaan ryhmän jäsenille kokonaan toisistaan poikkeavia, liikesarjaan soveltuvia osaliikkeitä".37

Tämäkin ohje painotti, että esityksen ensimmäisenä johtotähtenä tuli olla "laulun sanat ja sisältö". Liikkeiden tehtävänä oli siten tukea laulun sanomaa. Kisällit sijoittivatkin ne tavallisesti tiettyjen avainsanojen kohdalle - liikkeet eivät muodostaneet näin itsenäistä kokonaisuutta, vaan ne olivat alisteisia tekstin sanomalle. "Liikkeiden avulla saamme iskettyä jonkin haluamme kohdan kuuntelijoiden tajuun selvästi", em. Terän kirjoitus selvitti liikkeiden perimmäistä tehtävää (Anon. 1945a). Kisällien koreografia muistutti näin eräänlaista kuurojen kieltä, jossa sanallinen ilmaus sai tuekseen samaa asiaa tarkoittavan eleen.

Kun katselee kisälliesityksiä vanhoilta filmeiltä38, ei voi välttyä vertaamasta niitä mielessään niihin laululeikkeihin, joita lapset ympäri maailmaa leikkivät. Kisällien eleet ja temput eivät juuri poikkea naiviudessaan lastenperinteestä. Kuitenkaan kisällilaulu ei ollut lastenperinnettä, vaan aikuistuvien ihmisten poliittista ja viihteellistä musiikkia. Lapsenomaisuuden vaikutelma saattaakin olla harha, joka aina väijyy jälkikäteisarviointien takana. On syytä pitää mielessä, että koko sodanjälkeinen viihdekulttuuri elokuvat, iskelmät ja populaarikirjallisuus - näyttävät tämän päivän näkökulmasta varsin viattomalta ja lapsenmieliseltä puuhalta.

$* * *$

Lopuksi on syytä miettiä, mitä sangen yhtenäinen kisälliperinne kertoo musiikin asemasta poliittisessa organisaatiossa. Järjestöelämän kannalta yhtenäisessä poliittisessa laulussa oli monia hyviä puolia. Työväenliikkeessä eli vahvana kollektiivisuuden idea, joka edellytti, että kaikki harrastustoiminta oli joukkojen toimintaa. Kisällilaulussakaan ei ollut tärkeää omintakeisuus, vaan se, että lähes jokainen nuoriso-osasto kykeni siihen osallistumaan. Selvät mallit ja kaavat edistivät perinteen leviämistä nuorten keskuuteen.

Kisälliharrastus oli ylhäältä ohjattua, mikä oli omiaan korostamaan järjestön voimaa jäsenistöön nähden. On myös muistettava, että kisällilaulu 
oli ennen kaikkea poliittista propagandaa, se oli työväenliikkeen poliittinen ase. Laulut olivat monesti poliittisesti tärkeitä, ja järjestön oli kyettävä valvomaan niiden sisältöä. Tämä kävi helpommin, kun ohjelmisto oli yhtenäistä ja tyyli tarkan mallin mukainen.

Mutta kaavamaisuus voi myös tappaa harrastuksen, varsinkin jos harrastaminen on perustaltaan taiteellista ja luovaa. Ei liene sattuma, että kisälliesitysten kaavamaisuutta ilmaisevat kommentit ajoittuvat etupäässä 1950-luvun lopulle ja 1960- luvulle. Tuolloin kisälliperinne oli jo selvästi kuivettumassa ja rappeutumassa. Tämä laulumuoto ei kyennyt enää uudistumaan spontaanisti; laulujen teko ei lähtenyt enää ryhmistä itsestään, vaan järjestöt pitivät sitä hengissä tehokkaan organisaation, kurssitoiminnan ja järjestökurin voimalla. Edessä oli ainoastaan toiminnan loppuminen.

Silti kisällilaulu kykeni säilymään vireänä harrastusmuotona yllättävän pitkän ajan. Olivathan kisällit lähes 30 vuotta työväeniltamien ehdottomana vetonaulana, ohjelman kohokohtana. Yleisö odotti heitä suurella kiinnostuksella, ja illan lauluista riitti usein puhumista vielä iltamien jälkeenkin.39 On siis aiheellista pohtia myös, mikä oli kisällilaulun suosion salaisuus? Suosioon oli ainakin kaksi selvää syytä. Ensinnäkin kisällilaulu perustui kansanhuumoriin - sen sanontatapa ja muoto olivat työläisille tuttuja, ja he ymmärsivät helposti sen sanoman. Kisällit liikkuivat usein aikansa populaarimusiikin vanavedessä. Kun laulujen melodiat olivat usein päiväniskelmiä, varsinkin nuorempi iltamayleisö lämpeni kisällien esityksistä. Kaiken lisäksi vauhdikkaat liikkeet lisäsivät esitysten viihteellistä vaikutelmaa. Tavallaan kisälliryhmät olivat eräänlaisia poptähtiä omassa yhteisössään.

Toiseksi työläiset arvostivat kisällilaulua sen poliittisen voiman vuoksi. Kisällit toivat esiin samat asiat kuin iltaman poliittinen puhuja. Mutta he tekivät sen nasevammin, kärkevämmin ja ymmärrettävämmin. Kontrasti kuiviin poliittisiin liturgioihin nähden oli varsin suuri.40

Kisällilaulun tehokkuus ja suosio saattoi olla myös ongelma iltamien ohjelman kannalta. Työväenjohtajille puheenpito oli arvo sinänsä, eivätkä he pitäneet siitä, että kisällit villitsivät liiaksi yleisöä ja häiritsivät näin poliittisen sananjulistuksen perillemenoa. Reino Sandell selvitteli 1940-luvun lopulla tätä ongelmaa kansandemokraattien iltamien järjestäjille:

-- Ennen juhlapuhetta on yleisö saatava hiljentymään ja vakavoitumaan, muuten se ei seuraa puhetta. Samoin täytyy yleisölle antaa tilaisuus hetken ajatella kuulemaansa. Siksi on puhe syytä sovittaa viimeiseksi ennen väliaikaa. Missään tapauksessa ei esim. kisällilauluja saa asettaa juuri puheen edelle, sillä jos yleisö nauraa vielä puheen alkaessa, ei se syvenny kuuntelemaan koko puheen aikana. Tämän on kokemus osoittanut. (Sandell i.v., 3-4). 


\section{Viitteet}

1. Lainasävelmiä koskevat yleistykset perustuvat Työväenmusiikki-instituutin (TMI:n) laulukokoelmien läpikäyntiin.

2. STN:n kisällilaulut 1930-1944, TMI.

3. Väinö Tähkän ja Taisto Jermilän haastattelut 1977, Rajamäen Pojat -kokoelma, TMI.

4. Mm. Eero A. Oksasen haastattelu 1984, TMIc 1984-1; nimitys esiintyy myös ryhmän laulujen nimissä, esim. "Rajamäen köörin juhannusveisu" (1927), Rajamäen Poikien lauluvihko, TMI.

5. Väinö Tähkän haastattelu 1977.

6. Rajamäen Poikien lauluvihko, TMI; mustakantinen vihko sisältää käsinkirjoitetut sanat kaikkiaan 68 lauluun; niistä ensimmäisen, "Rajamäen romanssin" kohdalla on päiväys 26.1.1926; kirjan viimeinen päiväys 21.6.1928.

7. Pasilan Laulu-Jussien lauluvihko; Anna-Liisa Heinosen haastattelu 1977, TMI:n arkisto.

8. Taisto Jermilän haastattelu 1977; TMId 1983-4:57 (Kaarlo Kivilahti).

9. Tämä johtui paljolti siitä, että kommunistien poliittinen toiminta lakkasi lähes täysin 1930-luvun taitteessa. Agitaatiolaulun perinne jatkui nyt pelkästään sos.dem. nuorisoliikkeen piirissä; Neuvostoliiton esikuva ei ilmeisesti vaikuttanut kovinkaan paljon sos.dem. nuorison kisällitoimintaan.

10. Esim. TMIc 1982-9:33 (Pekka Saarnio); 1982-3:34 (Jaakko Kuusela); TMId 19834:31,37 (Eila Hirvonen, Vate Haimi)

11. Työväenliikkeen toisen osapuolen tietoinen tai tiedostamaton ignorointi tulee usein esiin haastatteluissa, jotka koskevat järjestötoiminnan vaiheita. Tuntuu usein siltä kuin toverit eivät olisi tienneet kilpailevan puolen toiminnasta mitään.

12. Muistitiedossa ja aiemmissa tutkimuksissa usein toistuva sos.dem. kisällitoiminnan perustamisvuosi 1927 on siten väärä; toiminta alkoi Suomessa vasta vuotta myöhemmin. STN:n edustajakokouksen pk. Helsinki 1928, 6; vrt. TMId 1983- 4:47-50 (Niilo Helismaa); TMId 1983-2:70 (Lauri Kuosmanen); Matkakertomukset 1929-1938, SSN:n paperit, Kansan Arkisto.

13. Karvonen 1948, 47; TMIc 1982-24:4,6 (Meeri Elo); 1984-2:9 (Anna-Liisa Hyvönen).

14. Kankaanpää 1951, 78; Toimintakertomus 1949, SDNL:n liittokokouspaperit, Kansan Arkisto.

15. Liittojuhlia ja kulttuurikilpailuja koskevat lehtiartikkelit Terässä ja Vihurissa 1950-luvulla.

16. Mm. TMId 1982-2:26 (Reino Sandell).

17. Mm. TMIc 1984-2:12 (Anna-Liisa Hyvönen)

18. TMId 1982-2:25 (Reino Sandell)

19. Mm. TMIc 1983-5:1 (Pauli Salonen); TMIc 1981-34:27 (Veikko Riipinen).

20. SDNL:n kisällilaulut 1950-luvun alusta, TMI. 
21. Mm. TMIc 1982-18:B1 (Anja Jämsen); TMId 1983-2:55 (Tanja Hietala).

22. Kaikki mainitut laulut sisältyvät SDNL:n kisällilaulukokoelmaan, TMI.

23. Esimerkkinä tästä voidaan mainita Lauritsalan kisällien ja kisällittärien yhteisesti esittämä "Nuorten työläisten lippulaulu", joka lauletaan Taistojen tiellä -laulun sävelmällä. Esitys on videonauhalla TMI:n kokoelmissa.

24. Ks. Kurkela 1986, erit. 115-138, jossa asiaa käsitellään laajasti.

25. Lappeenrantakokoelma, videonauhoitus, TMI.

26. Työväen muistitietokokoelma 204:10, Työväen Arkisto.

27. Ks. Kurkela 1983, 86-91, jossa kuvataan Varkauden työväenyhdistyksen soittokunnan vaikeuksia jatsimusiikin "uhan" alla. Myös Työväen Musiikkilehdessä oli 1930-luvulla usein mainintoja soittokuntien vaikeuksista.

28. Vrt. Hurri mt., 42; vaikka musiikkiliitossa on vallinnut koko ajan selvä sosialidemokraattinen hegemonia, kommunistit ovat voineet ajoittain yrittää "vallankaappausta" liiton johdossa. Esimerkiksi 1950-luvun taiteessa SKDL:ssa oli erityinen musiikkijaosto, joka ponnisteli voimakkaasti tähän suuntaan, siinä kuitenkaan onnistumatta; vrt. Kurkela 1986, 106-111, jossa asiaa käsitellään tarkemmin.

29. Mm. TMIc 1982-12:48 (Åke Ahremaa); TMIc 1982-1:17 (Helge Jämsen); TMIc 1982-7:17 (Martti Pöysälä); TMIc 1983-9:15-16 (Ahti Nieminen).

30. TMIc 1982-7:17 (Martti Pöysälä); "Kisällilauluista ja niiden esittämisestä". Ohjelmatyön paperit, Kansan Arkisto. i.v.

31. Kaikki mainitut kokoelmat ovat Työväenmusiikki- instituutin arkistossa.

32. TMIc 1982-12:36, -29:2 ( ̊ke Ahremaa); TMId 1983-5:19 (Kaarlo Kivilahti).

33. Nuorison kulttuuripäivien selosteet ja pöytäkirjat 1947, 1949, 1953, 1957, 1961, SNE:n paperit, Valtion Arkisto.

34. TMIc 1982-7:28 (Martti Pöysälä); TMIc 1981-32:18 (Hilkka ja Veikko Puustinen).

35. TMId 1983-2:70,72 (Lauri Kuosmanen).

36. Suomen Elokuva-arkistossa on on tallennettu joukko lyhytfilmejä ja niiden osia, joiden aiheena on kansandemokraattisten järjestöjen liitto- ym. juhlat 1940- ja 1950luvuilta. Niiden perusteella voi saada suhteellisen elävän käsityksen kisällien liikuntatyylistä.

37. Ks. viite 30.

38 . Ks. viite 36.

39. TMIc 1983-2:9-10 (Ossi Sjöman); TMIc 1983-11:4 (Olavi Hurri).

40. ibid.; TMIc 1984-2:25 (Anna-Liisa Hyvönen) 


\section{Lähteet}

A. ja 0.

1945 "Jälkikaikuja kisällikilpailusta". Työläisnuoriso 12/1945, 2.

Anonyymi

1936 "Musiikkijärjestöjemme syrjäyttäminen", Työväen Musiikkilehti 2/1936, 23.

1937 "Työväen juhlakulttuuri ja n.s. kisällilaulu", Työväen Musiikkilehti 2/1937, 27.

1945a "'Laulava sanomalehti'. Kisällilaulu kuntoon ja kunniaan!". Terä 1945/2.

1945b "Liittojuhlien ohjelmansuoritus". Terä 1945/6.

Ben-Amos, Dan

1972 "Toward a Definition of Folklore in Context". A. Paredes \& R. Bauman, ed. Toward New Perspectives in Folklore. Austin and London.

Bohman, Stefan

1985 Arbetarkultur och kultiverade arbetare En studie av arbetarrörelsens musik. Arlöv.

Bramsjö, Henrik \& Magnus Florin

1978 Blå Blusen. Arbetarteater på 30-talet. Lund.

Gronow, Pekka

1976 "Kisällilaulu". Paimensoitosta kisällilauluun, toim. H. Laitinen \& S. Westerholm. Alajärvi.

Heimann, Walter

1977 "Zur Theorie des musikalischen Folklorismus: Idee, Funktion und Dialektik". Zeitschrift für Volkskunde II/1977.

Hemmersam, Flemming

1978 "1. maj demonstration 1976 i Kobenhavn". Unifol. Årsberetning 1978, Koben havn.

Hodek, Johannes

1977 Musikalisch-pädagogische Bewegung zwischen Demokratie und Faschismus.

Weinheim und Basel.

Hoffmann, Ludwig \& Daniel Hoffmann-Ostwald

1972 Deutsches Arbeitertheater 1918-1933. Berlin.

Haaranen, Niilo

1948 "Propaganda vai taide tärkeämpää kisällilauluissa?". Työläisnuoriso 44/1948, 6.

Haataja, Lauri, Seppo Hentilä \& Jussi Turtola, toim.

1978 Suomen työväenliikkeen historia, III p. Joensuu.

Herndon, Marcia \& Norma McLeod

1981 Music as Culture. Darby

Huhta, Vihtori [V.H.]

1938 "N.s. kisällilaulut", Työväen Musiikkilehti 1/1938, 6.

1948 [H. Käpälämäki] "Kisällilaulut nuorisoliikkeemme ohjelmassa". Työläisnuoriso 6/1948. 
Hurri, Merja

1982 Suomen Työväen Musiikkiliitto 60. Tampere.

Hurri, Olavi

1950 "Miksi - ja miksi ei?". Työläisnuoriso 39/1950, 2.

Jalkanen, Pekka

1975 Ravintola- ja tanssiorkesterilaitoksen murros Helsingissä 1920-luvulla. Pro gradu -työ, Helsingin yliopisto.

Kankaanpää, Marjatta

1951 Työn nuorten taival Helsinki.

Karvonen, Toivo

1948 "Salaista ja julkista nuorisotoimintaa". SKP taistojen tiellä IV. Helsinki.

Kolland, Dorothea

1979 Jugendmusikbewegung, "Gemeinschaftsmusik" - Theorie und Praxis. Tübingen.

Kurkela, Vesa

1983 Taistojen tiellä soiteltiin - ja soiton tahdissa tanssittiin. Jyväskylä.

1986 Tanhuten valistukseen. Helsinki.

Manninen, Tapio

1948 "Mihin suuntaan ja tyyliin?", Työläisnuoriso 1948/42, 3.

Nokelainen, Uuno

1950 "Miksi - ja miksi ei?". Työläisnuoriso 43/1950, 7.

Palmgren, Raoul

1965 Työläiskirjallisuus. Porvoo.

Parkkari, Nestori

1970 Nuoret taistelun tiellä. Kuopio.

Saunio, Ilpo \& Timo Tuovinen

1978 Edestä aattehen, Tammi, Helsinki

Sandell, Reino [Santtu]

i.v. "Ohjeita kesäjuhliin", Kesäjuhlat, toim. R. Sandell \& al. Helsinki.

1948 "Laulavat sanomalehdet". Terä 1948/23-24.

Steinitz, Wolfgang

1962 Deutsche Volkslieder demokratischen Charakters aus sechs Jahrhunderten. Vol. 2. Altenburg.

Toivonen, Kauko

1950 "Kisälliryhmät 'rumputulessa'". Työläisnuoriso 47/1950, 7. 


\section{Summary}

\section{Kisällilaulu - agitation and entertainment}

The article presents the history and special features of the agitation song of the Finnish working youth movement (Fi. kisällilaulu - literally "journeymen's song"). The kisällilaulu groups came about in the 1920s with influences on the one hand from the propaganda movement of Soviet Russia (communist groups) and the sjungande gesäller groups of Sweden (social-democrats). The main period of the movement was in the decade following the Second World War when there were about 800 of the above singing groups in Finland, of which approximately half were communists and half were social-democrats. The kisällilaulu tradition remained part of the musical activities of organized working-class youth until the mid1960s.

The concepts of agitation and entertainment describe the main features and limits of the kisällilaulu tradition. The repertoire of the groups extended from clearly aggressive political songs to relatively innocent music-hall type entertainment. The repertoire included political satire, moralistic songs, inspiring marches and ordinary folk songs. The article concentrates on two issues central to the study of all music in folk movements. The first concerns the aesthetics of the kisällilaulu tradition and the second the specific ideal of discipline which is also clearly present in the tradition. From the perspective of established musical training and art music the kisällilaulu songs were hardly music at all. They were too unaesthetic and coarse. However, the songs were an effective means of political agitation and for this reason accepted and valued by the cultural leadership of the workers' movement. On the other hand, from the perspective of folk culture, i.e. in the view of the singers and their audience, the kisällilaulu tradition was valued and respected as music. The singers were often the main event at meetings and the most popular item on the programme. The song tradition had a clear aesthetic of its own which can be described as functional: the main purpose of the song was to deliver a political message to the audience as effectively as possible. The most important features of a performance were force and a clear presentation of the words of the songs. Singing in key, on the other hand, was not so important. In many of the groups the signing was more like rough shouting that could be described as unison singing with a poor rhythmic and melodic blend. Rhythmically the songs were intended to be precise and spirited. The accompanying instrument (mandolin, guitar or accordion) helped in this respect. 
The singular folk norms of the kisällilaulu tradition soon came into conflict with the artistic musical activities of the workers' movement and led to a need to develop the tradition in the style of bel canto, sung in parts. For most of the groups this was, however, an impossible requirement. The new style was too removed from the musical thinking of folk culture. With a few exceptions, the vocal groups kept to the old style which at the same time began to follow set patterns and repeat itself.

The rigidity of style is an integral part of the overall nature of music in political organizations. The kisällilaulu tradition was a typical example of music that was controlled and directed from above by the leaders of the central organizations. The aim was to create a form of music that could express the mass strength of the workers' movement and the collective ideal. Individuality or uniqueness were not important to the tradition. Of more importance was the requirement that the songs could be performed by all groups. The uniform nature of the tradition was emphasized by costumes, choreography and norms concerning the composition of the groups (separate vocal groups for girls and boys) as well as a uniform repertoire handed down from the central organizations.

At first the clear models and instructions facilitated the spread of this style of singing among working-class youth. They offered a basis for individual groups to develop their repertoire and style to a relative degree of versatility. However, strict adherence to set patterns is usually antithetic to artistic endeavour and by the late 1950s the kisällilaulu song tradition had clearly become too rigid in its forms and was dying out. It could not find ways of spontaneous renewal. The songs were no longer written by the groups themselves and the tradition was kept alive by the organizations through effective organization, courses for performers and discipline. In this situation the tradition could only expire. 